\title{
Regulated electricity networks, investment mistakes in retrospect and stranded assets under uncertainty
}

\author{
Paul Simshauser*^ \& Alexandr Akimov ${ }^{\star}$
}

August 2018

\begin{abstract}
From 2004 to 2018 the Regulatory Asset Base (RAB) of electricity networks across Australia's National Electricity Market tripled in value, from $\$ 32$ billion to $\$ 93$ billion. The run-up in the capital stock was driven by forecast demand growth and a tightening of reliability standards. But demand contracted from 2010-2015. With a rising $R A B$, contracting demand and a regulated revenue constraint, an adverse cycle of falling demand and sharply rising tariffs appeared to be emerging. Some networks were characterised by significant investment mistakes in retrospect, and perhaps unsurprisingly, various consumer groups and regulatory bodies argued assets should be stranded or written-off with network tariffs reduced. From 2015-2018, energy demand increased once again. In this article we present a method for dealing with stranded assets under uncertainty; rather than permanently stranding assets that fail a used and useful test, we reorganise the financial and economic affairs of a template network utility and "Park" excess capacity, issue credit-wrapped bonds to temporarily finance the stranded capital stock, then re-test the Parked Assets at the end of each five-year regulatory determination. Parked Assets can then be "UnParked" and returned-to-service in line with connections growth, load growth, or both. This produces an immediate reduction in network tariffs under our generalised assumptions, but scarce government balance sheet capacity is necessarily utilised and recovery risk is transferred from shareholders to taxpayers. Accordingly, a Park and Loan policy is not a costless exercise.
\end{abstract}

Keywords: Electricity Utilities, Falling Demand, Stranded Assets. JEL Codes: D4, L5, L9 and Q4.

\section{Introduction}

Australian residential electricity tariffs rose sharply over the period 2007-2015. Climate change policies, solar Feed-in Tariffs and Australia's 20\% Renewable Portfolio Standard contributed to increases but the overwhelming driver related to regulated network tariffs. ${ }^{1}$ Significant investment mistakes in retrospect occurred, commencing from 2004. Indeed, from 2004-2018 the Regulatory Asset Base (RAB) of electricity networks across Australia's National Electricity Market (NEM) tripled in value, from $\$ 32$ billion to $\$ 93$ billion. The runup in the capital stock was driven by forecast demand growth and a tightening of reliability standards by policymakers.

Power system load growth during the late-1990s to mid-2000s, particularly in NEM regions such as Queensland, were surprisingly strong due to mining-related demand expansion and the rapid uptake of air-conditioners in the residential sector. In 2004, a series of unfortunate network-related load-shedding events occurred in the capital cities of Sydney and Brisbane. As Helm (2014) explains, an energy market crisis will induce an inquiry, an inquiry will produce policy recommendations, and some policy recommendations will be misguided because the market is rarely afforded an opportunity to scrutinise their (entirely predictable) unintended side-effects. In this instance, the misguided policy recommendation was to tighten network reliability standards to reduce the incidence of load-shedding events - with a

\footnotetext{
* Professor of Economics, Griffith Business School, Griffith University. Views expressed in this article are those of the author.

- Associate, Energy Policy Research Group, University of Cambridge.

- Senior Lecturer in Banking \& Finance, Griffith Business School, Griffith University.

${ }^{1}$ The Australian Competition \& Consumer Commission found the average electricity bill had increased from $\$ 1210$ to $\$ 1636$

$(+35.2 \%)$ over this period. The single largest contribution was network charges, up \$148 or 35\%. See ACCC (2018 at p.6). 
predictable (and predicted) unintended side-effect being Averch \& Johnson (1962) goldplating. ${ }^{2}$ The combination of forecast load growth and tighter reliability standards led to record levels of capital expenditure between 2005-2015, as Figure 1 illustrates.

Figure 1: $\quad$ Network Capital Expenditure (1979-2018 - Queensland)

(Constant 2018 \$)

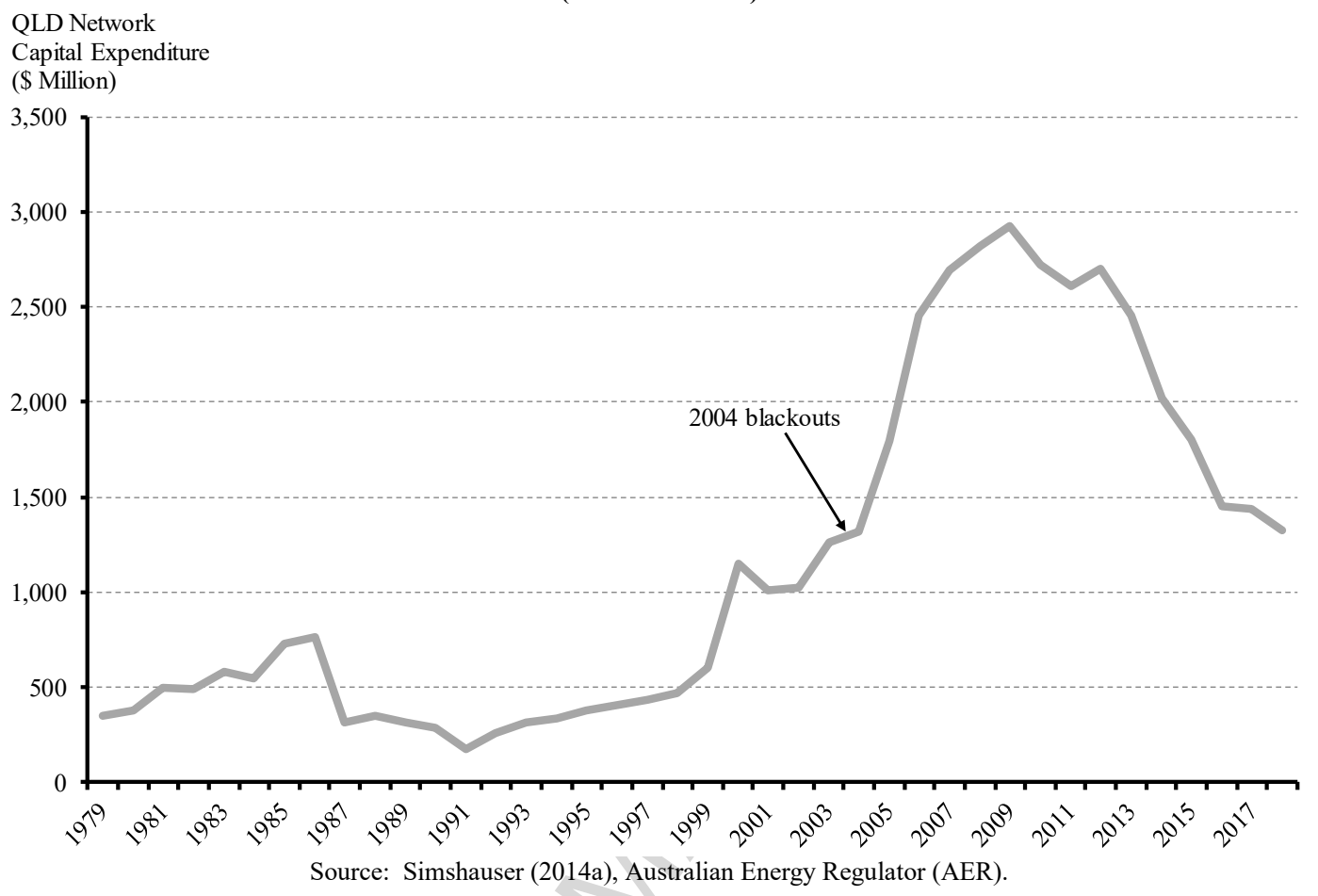

An energy market crisis usually involves many things going wrong at once. In Australia, power was first produced in 1882 and from that moment onwards Australian final electricity demand experienced continuous year-on-year growth regardless of economic conditions. ${ }^{3}$ But the Global Financial Crisis and disruptive competition in the form of distributed resources combined to produce the first sustained contraction in final electricity demand in Australian power industry history from 2010 (see Figure 2 - LHS axis). Thus, not only did prior-period load forecasts prove too optimistic, load began to contract in a manner consistent with a network in decline - colloquially known as a utility death spiral, and formally defined as a network experiencing a sustained, non-temporary reduction in demand that produces excess capacity on large parts of a network (Decker, 2016). By 2015, NEM energy demand (GWh) had fallen to 2004 levels. Consequently, rather than deploying scarce capital productively to meet power system load growth, significant network capital investment mistakes in retrospect merely added an expensive layer of excess capacity ${ }^{4}$ (see Figure $2-$ RHS axis).

\footnotetext{
${ }^{2}$ See Simshauser (2014a) for further details.

${ }^{3}$ Negative demand growth was experienced in Tasmania (1968, 1983, 1995, 2005-2006), New South Wales (1983 \& 2005),

Queensland (2004) and in South Australia (1984, 1996, 2002 \& 2004) but combined, the NEM regions posted persistent year-onyear growth until 2010 .

${ }^{4}$ As described by Pierce (1984) albeit in relation to a similar pattern with nuclear power stations in the USA.
} 
Figure 2: $\quad$ NEM System Load 1990-2018 and Network Regulated Asset Base

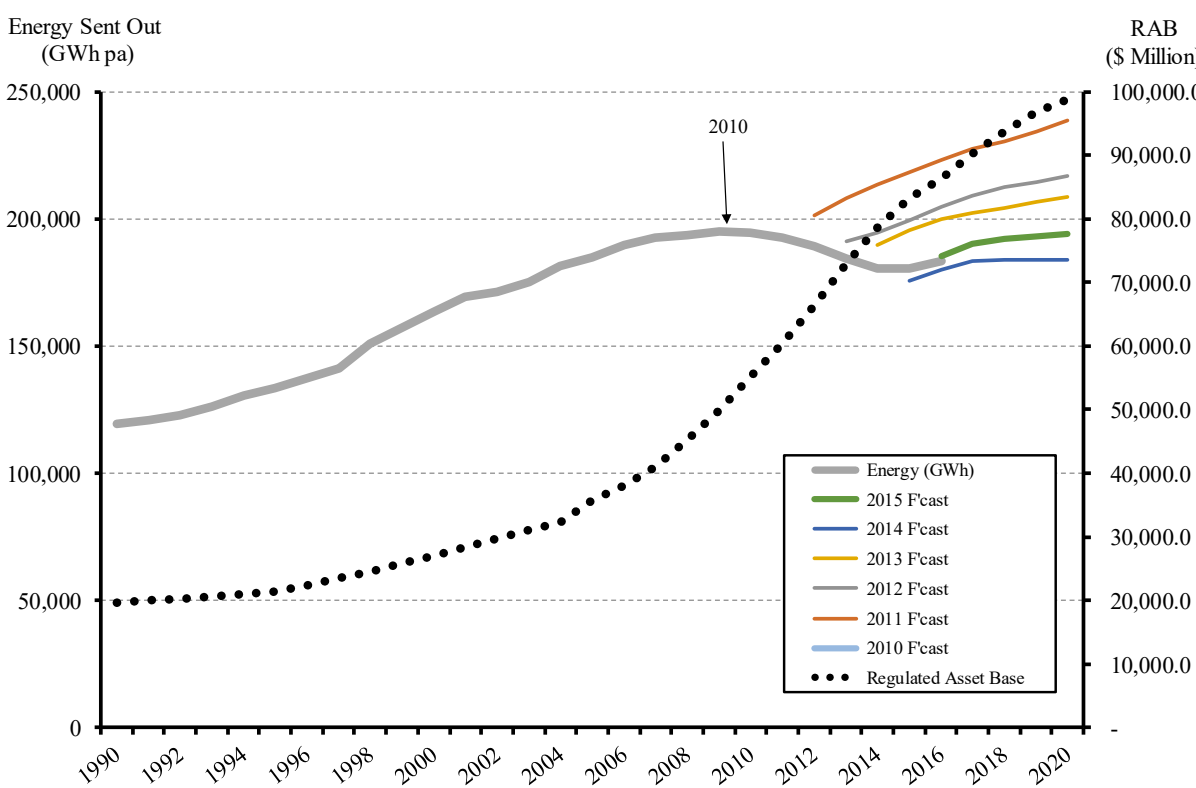

Source: Energy Supply Association of Australia (esaa), Australian Energy Market Operator (AEMO), Simshauser (2018a).

Compounding matters, when regulatory determinations were being finalised the financial markets (bond markets in particular) were experiencing their worst conditions since the 19291932 financial crisis. ${ }^{5}$ These conditions fed directly into Capital Asset Pricing Models and produced a very high regulated rate of return for the monopoly utilities. As a result, investment mistakes in retrospect were then amplified by an elevated regulated rate of return (noting that no error was involved in rate of return determinations). When combined with contracting load, retail-level tariffs increased from $12.54 \mathrm{c} / \mathrm{kWh}$ in 2007 to $29.34 \mathrm{c} / \mathrm{kWh}$ by 2015 - a compound annual growth rate of $11.2 \%$ or $8.3 \%$ above the $2.7 \%$ average annual inflation rate as illustrated in Figure 3.

Figure 3: $\quad$ Average Residential Tariffs (1955-2019 - Queensland)

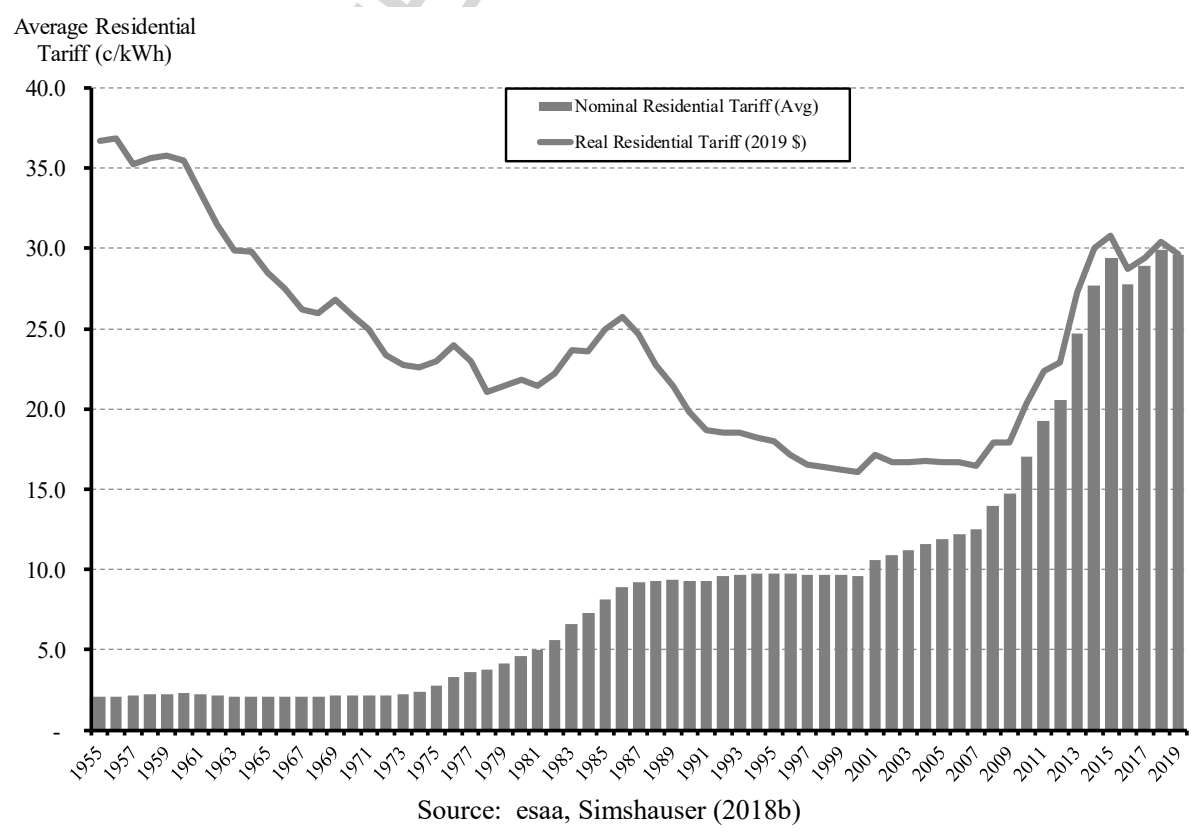

Rising tariffs induced a Demand Response for grid-supplied electricity, and as the forecasts in Figure 2 tend to indicate, at levels not previously seen in part due to rooftop solar PV. For a large household consuming $7562 \mathrm{kWh}$ per annum, installing a $5 \mathrm{~kW}$ system (current installed 
cost of $\sim \$ 4000$ ) reduces grid supplied power by $-40.5 \%$ to $4,497 \mathrm{kWh}$. The potential impact of battery storage could intensify grid loses to $-63.0 \%$ as Figure 4 illustrates:

Figure 4: Household summer load ${ }^{6}$, solar PV and battery storage impacts

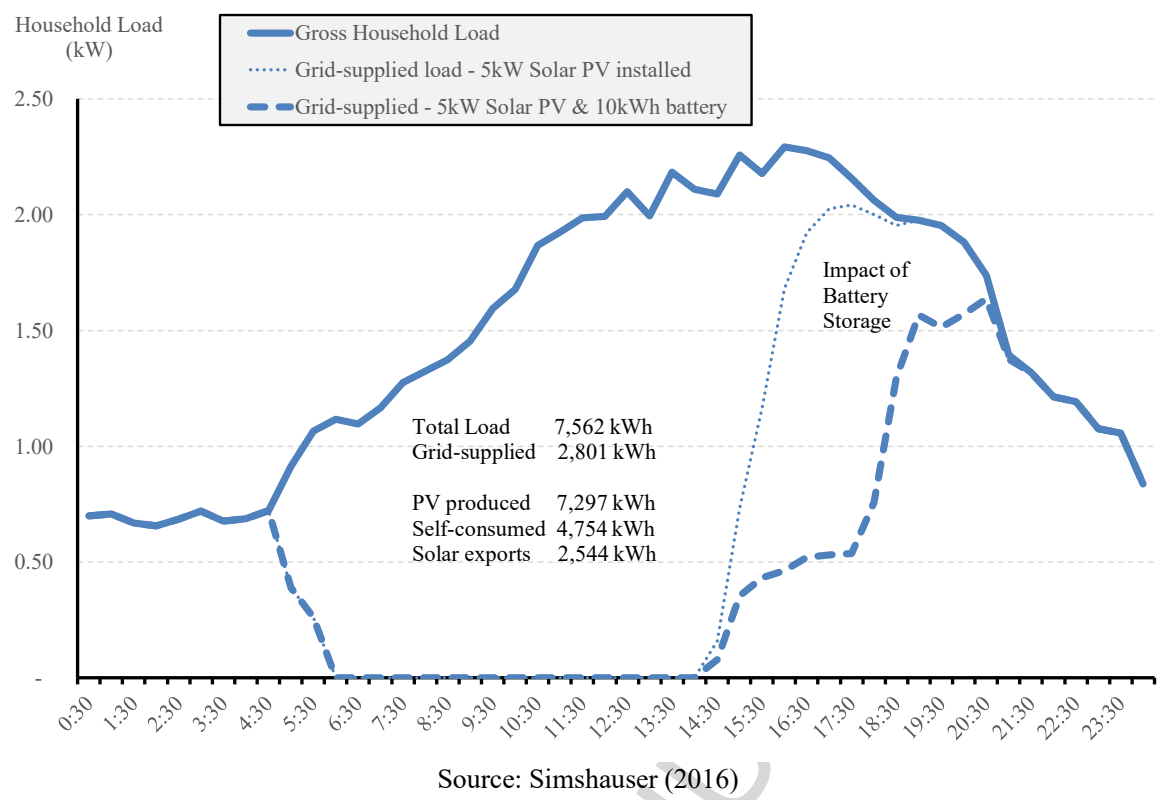

With the uptake of solar PV by more than $30 \%$ of detached households in regions such as Southeast Queensland, network load was progressively hollowed-out (see Figure 5). This, coupled with inadequate tariff design, produced a genuine risk of networks in decline ${ }^{7}$.

Figure 5: $\quad$ Distribution Network 'Net System Load Profile' in Southeast Queensland 2009-2015

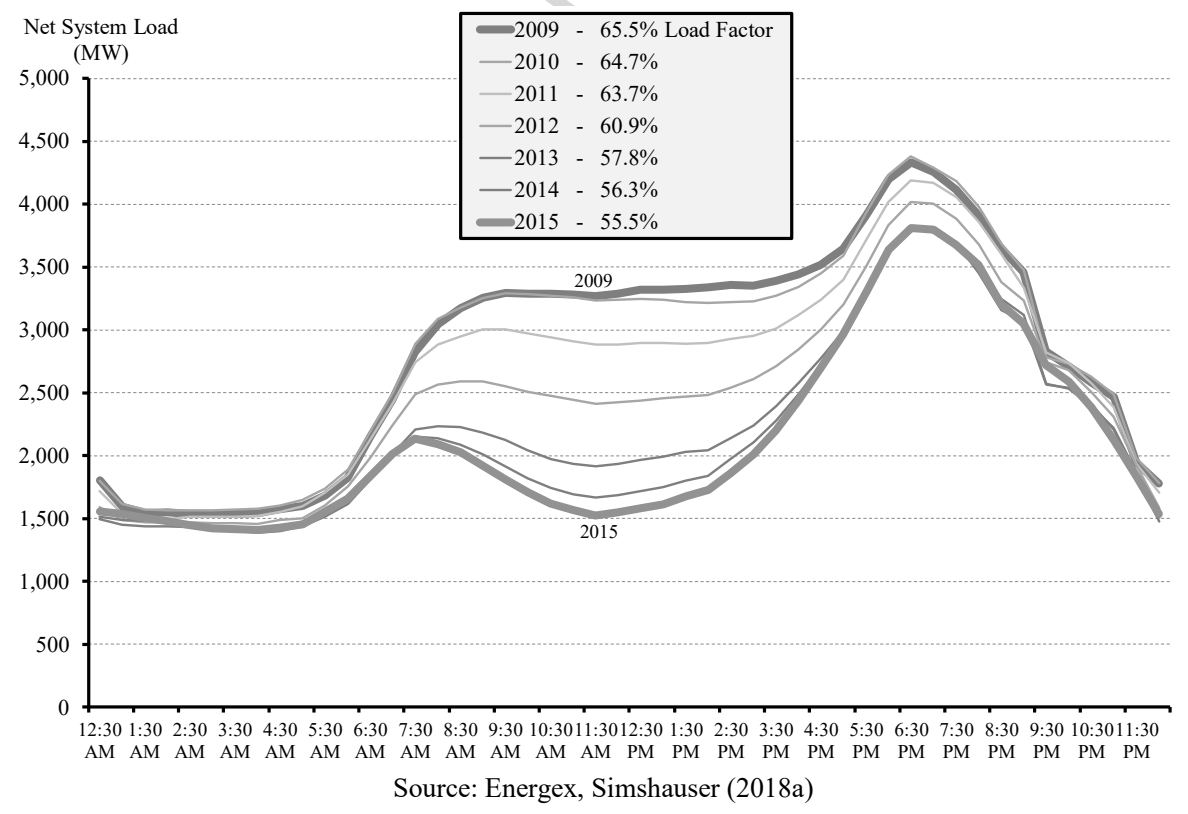

When significant investment mistakes in retrospect are combined with a network in apparent decline, a certain level of assets will fail a used and useful test and will ultimately meet the definition of stranded assets, i.e. assets unlikely to be supported by future net revenues (Simshauser, 2017). In the Australian case, there have been numerous calls for network asset stranding (see Mountain, 2014; Grant, 2016; Grattan, 2018; ACCC, 2018).

\footnotetext{
${ }^{6}$ This chart displays the average household load during 12 critical event days of summer with the full underlying annual data set with 30 minute resolution at the customer switchboard circuit level (i.e. including general power, air conditioning, hot water heating, lighting and cooking appliances) available in Simshauser (2016).

${ }^{7}$ See also Simshauser (2016)
} 
A decision to pursue a large-scale asset stranding programme would likely require a well settled view of a network in decline. But rarely are policy and regulatory problems clear cut. In practice, future energy demand and electricity network use is inherently uncertain. We suspect few regulatory rule books are pre-populated with suitable policy prescriptions for clear-cut episodes of stranded assets, let alone uncertain, forward market conditions. Conversely, a failure to deal with significant investment mistakes in retrospect produces static efficiency losses and the allocative inefficiency that arises is likely to exacerbate a network in decline through investments in bypass options above the efficient level.

In this article, we develop a potential policy prescription for dealing with stranded assets under uncertainty ${ }^{8}$. Rather than permanently stranding assets that fail a used and useful test, our prescription aims to temporarily Park excess capacity; we then proceed to re-organise the financial and economic affairs of a template network utility by issuing government-sponsored (credit-wrapped) bonds to temporarily finance the Parked RAB's underlying debt. This produces an arbitrage between the network cost of capital, and the ultra-low cost of government-wrapped bonds. The Parked RAB balance is then re-tested on a used and useful basis at each five-year regulatory determination, at which point Parked Assets are Un-Parked and returned-to-service in line with customer connections growth, demand growth, or both.

The most interesting result is the immediate impact on network tariffs - as expected Parking the assets and securitisation of the stranded debt (and associated cost of capital arbitrage) produces a material reduction in tariffs under our generalised assumptions and provides time to assess when to return Parked Assets to service. However, securitising debt transfers recovery risk from shareholders to taxpayers, and scare government balance sheet capacity is necessarily utilised. Consequently, and to be perfectly clear, the purpose of this article and our policy prescription more generally are to show what can be done, not what should be done.

This article is structured as follows. Section 2 reviews relevant literature. Section 3 presents a Regulated Monopoly Model and our Base Case scenario. Section 4 analyses the "Park and Loan" policy. Conclusions follow.

\section{Review of Literature}

A number of explicit and implicit assumptions underpin monopoly price regulation. Among the most fundamental implicit assumptions is growth in demand relative to growth in total network costs. As Decker (2016) explains, the $20^{\text {th }}$ Century was characterised by ever expanding demand for utility services, and this underpinned a general stability of tariffs. But if this relationship breaks down such that demand growth stalls or contracts while cost growth remains non-negative, the mechanics of price regulation produce an increasingly unstable tariff trajectory (Simshauser, 2017).

Historically, significant investment mistakes in retrospect, which might cause a temporary surge in cost growth relative to energy demand, could be "sweated out" with comparatively little damage done to overall economic efficiency. Constant population growth and an expanding economy could be relied upon to produce ever higher power system demand and thus planning errors would self-correct over time. But various jurisdictions are now experiencing networks in decline in the traditional utility services of electricity, gas, fixed line telecoms and postal services.

Significant investment mistakes in retrospect combined with an electricity network in decline will present policymakers and regulators with serious problems because the outcomes for consumers are in stark contrast to competitive markets (Simshauser, 2017). In the competitive generation market, investment mistakes in retrospect and declining demand result in (1) excess capacity, (2) falling spot and forward prices, (3) asset write-downs, (4)

\footnotetext{
${ }^{8}$ The authors would like to acknowledge Mr Brian Carrick from Queensland Treasury Corporation, who described this concept to Prof. Simshauser (then Director-General of the Department of Energy \& Water Supply) in 2017.
} 
shareholder losses and (5) gains in consumer surplus through falling prices. Conversely, investment mistakes in retrospect and declining demand for a regulated network monopoly results in (1) a higher RAB, (2) a higher annual revenue requirement, (3) a correspondingly higher regulated tariff, (4) stable returns to shareholders, and (5) welfare losses borne entirely by consumers through higher tariffs.

Economic theory and the great regulatory treaties of Bonbright (1961) and Kahn $(1970,1971)$ are silent on the concept of networks in decline and how to treat the stranded assets of regulated monopoly utilities. Recognition of the problem can be traced back to Hotelling (1938, p266), who first described the modern-day utility death spiral, viz. declining demand being aggravated by rising monopoly tariffs. Beyond this, literature can be traced at least as far back as Pierce (1984), Joskow \& Schmalensee (1986) and Hoecker (1987) who focused on supply-side investment mistakes in retrospect, while MacAvoy et al $(1989$, p.214) first described the risk of a network in decline arising from disruptive competition.

A wealth of literature would subsequently emerge in the US during the 1990s due to FERC Order $888^{9}$ which as a policy had the effect of stranding monopoly generation assets with full economic recovery for shareholders. Recovery was typically by way of long-dated, nonbypassable stranding charges and in some cases credit-enhanced through the issuance of transition bonds (Joskow, 1996a; Michaels, 1998).

\subsection{Two branches of stranded asset literature in the 2010s}

Interest in stranded assets re-emerged in the 2010s in two distinct but related branches; the first arose primarily in response to risk factors relating to the environment (see Caldecott, 2015; Caldecott, 2017; Kruitwagen et al. 2017 amongst others). While covering a very broad range of asset classes and sectors, the risk of stranded fossil fuel reserves and coal-fired generation plant are dominant and recurring themes in this branch of the literature (see for example Caldecott, Dericks \& Mitchell, 2015; Lucas, 2016; Buhr, 2017; Silver, 2017; Covington, 2017; Green \& Newman, 2017; Mercure et al. 2018; Pfieffer et al. 2018; Rozenberg et al. 2019).

The second branch has a more narrow focus on the risk of stranded regulated monopoly network assets due to forecast error and changes in the pattern of demand (see for example Faruqui, 2013; Graffy \& Kihm, 2014; Sioshansi, 2014; Simshauser, 2014a; Crawford, 2014; Crawford, 2015; Grant, 2016; Simshauser, 2016; Decker, 2016 ${ }^{10}$; Simshauser, 2017). The second branch of the literature therefore deals with excess network capacity.

What distinguishes the first branch of the literature from the second is i). the nature of the original investment (i.e. the latter are regulated assets) and ii). the expected future role of the respective asset classes in an energy system transition, and specifically, the inevitability of asset stranding.

For any power system, credible decarbonisation pathways necessarily involve the early retirement (i.e. stranding) of coal-fired generation plant (Caldecott, Dericks \& Mitchell, 2015; Lucas, 2016; Covington, 2017; Rozenberg et al. 2019). Consequently, the stranding of such coal assets has a certain level of inevitability.

In contrast, while distributed energy resources have altered the pattern of demand and contributed to an environment of minimal or negative demand growth, it is not inevitable that the role of the regulated transmission and distribution networks will decline. First, as Figure 2 tends to indicate, after an initial reduction in energy demand, the power system has seen a return to growth in total system load, albeit at minimal growth rates and with considerable

\footnotetext{
${ }^{9}$ Federal Energy Regulatory Commission (FERC) Order 888 was enacted 24 April 1996, and had the effect of stranding generation assets of approximately $\$ 135$ billion in value. See Rose (1996) for a summary of the standing estimate undertaken by Moody's.

${ }^{10}$ Decker also catalogues numerous contemporary contributions from fixed line telecommunications and traditional postal services.
} 
excess capacity remaining. In the long run, such capacity may be absorbed by ongoing network connections, and as the transport sector transitions, via new demand from electric vehicles.

Second, networks exist to facilitate gains from exchange - and intermittent renewable generation, both utility and rooftop-scale, are characterised by material supply imbalances vis-à-vis final demand. Thus, while Figure 4 tended to suggest large reductions in gridsupplied load for households that install solar PV, what it did not reveal were how such households use the network in reverse for solar exports. This data is illustrated in Figure 6 (using average daily data) and shows that while household load reduces after installing a $5 \mathrm{~kW}$ solar PV system, solar PV exports require even greater network capacity (noting that network capacity requirements are driven by maximum $\mathrm{kW}$ load rather than $\mathrm{kWh}$ throughput). Indeed, several distribution network feeders in the State of Queensland have reached their limits via reverse flows (i.e. solar PV exports).

Figure 6: Household use of grid with 5kW solar PV system

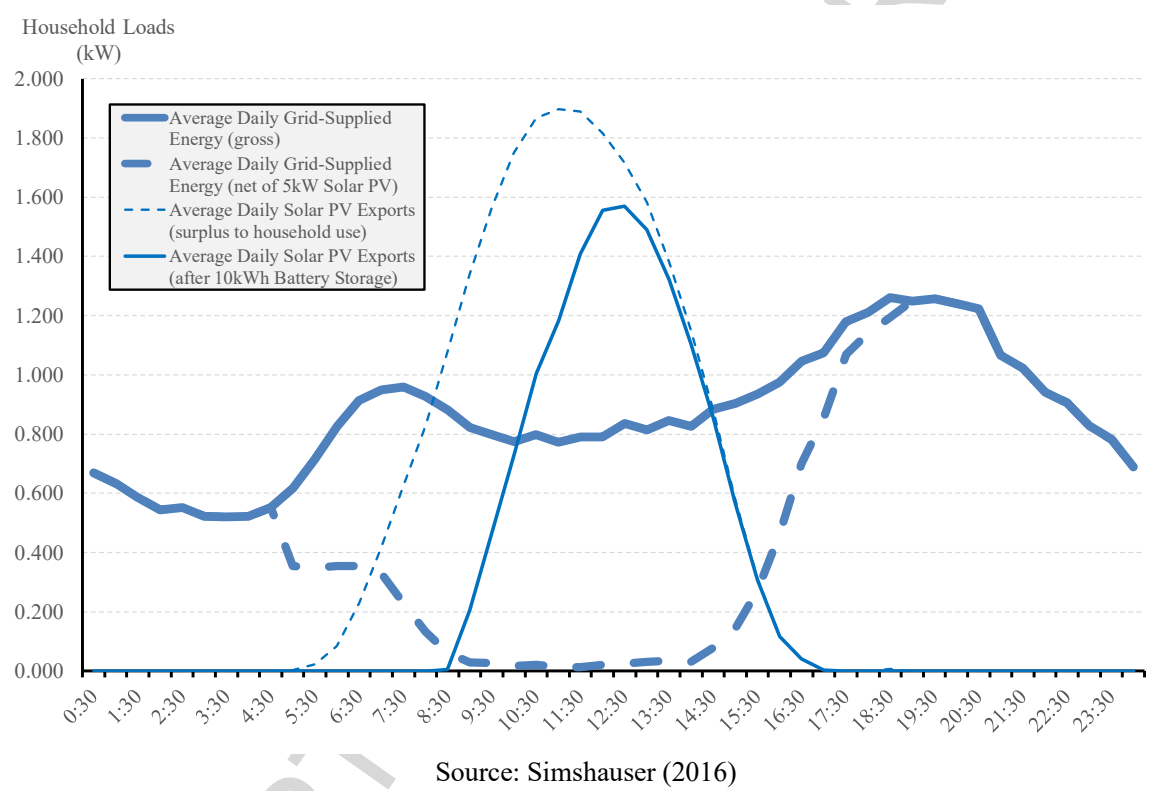

In the present article, we deal specifically with the second branch of the literature, viz. a regulated monopoly network characterised by significant investment mistakes in retrospect, with tariffs rising above efficient levels. If such a network is experiencing inadequate growth in demand to "sweat out" the problem, asset stranding may become necessary in order to avoid bypass above the efficient level, and, to stabilise tariffs and ensure an equitable recovery of a network's onerous sunk costs.

The regulatory and policy challenge that therefore follows is (1) what assets are to be stranded $^{11}$, and (2) the level of recovery - that is, what percentage of stranded assets should be recovered by non-bypassable charges, and what if any should be written-off? The complexity of asset stranding policy for regulated network monopoly is underpinned by the fact that efficiency arguments compete with fairness arguments (Hogan 1994; Baumol \& Sidak 1995), the amounts at stake are inevitably large (Tye \& Graves 1996; D'Souza \& Jacob, 2001; Ritdchel $\&$ Smestad, 2003) and all available remedies ${ }^{12}$ produce a zero-sum game - any credible solution at least partially unwinds the very benefits arising from the cause of stranded assets (Navarro, 1996; Wen \& Tschirhart 1997). In the case of FERC Order 888, the full (i.e. $100 \%$ ) recovery of stranded assets was justified on the basis of (1) the regulatory compact, (2) maintaining power system financial integrity, and (3) cost causation (McArthur, 1998). This was however a contentious decision (Rose, 1996).

\footnotetext{
${ }^{11}$ Note that ultimately it is the tariff that is stranded rather than specific physical network assets per se (see Simshauser 2017).

${ }^{12}$ Recovery typically occurs via accelerated depreciation, supra-competitive prices or non-bypassable surcharges.
} 


\subsection{The regulatory compact $\&$ incumbent burdens}

The regulatory compact can be traced back to $1983^{13}$ and is largely consistent with Kydland \& Prescott's (1977) theory of dynamic inconsistency. From a fairness perspective, utility investors make vast financial investments in long-lived assets to serve the public in exchange for a guaranteed rate-of-return. If a regulator approves as prudent a series of network investments at the time of commitment, and then subsequently deems such assets as stranded, capital markets (i.e. both debt and equity capital markets) will interpret policy as opportunistic and heighten the cost of capital in future regulatory periods, produce investment frictions and potentially block investment (Baumol \& Sidak, 1995; Woo et al. 2003; Douglas et al. 2009; Kind, 2013).

MacAvoy et al. (1989, pp224-230) highlight incumbent burdens - tariff rigidity, an inability to adopt more efficient market segmentation through discriminatory prices, Universal Service Obligations, minimum service standards, limits on long term contracts, conflicts amongst regulation, policies which subsidise bypass (e.g. solar Feed-in Tariffs) and other mandated environmental schemes all deviate from minimum cost (see also Hogan, 1994; Navarro, 1996; Boyd, 1998; Pagach \& Peace, 2000; Martin, 2001; Decker, 2016; Simshauser, 2017). As MacAvoy et al (1989, p245) noted:

A commonly overlooked feature of most bypass settings is that bypassing customers not only receive the service that they purchase from [for example, Solar PV \& Battery Storage], but also obtain back-up service from the existing utility at no substantial cost to them...

Policymakers and regulators frequently force utilities to make sub-optimal investments to meet policy objectives and incumbent burdens, and such investments were only originated because returns were guaranteed. Economics may not provide a basis for systematic conclusions on matters of equity and fairness, but stranding these asset categories without recovery does present an 'inescapable issue of procedural fairness' (Baumol \& Sidak, 1995, p.843). ${ }^{14}$ Crawford (2014) outlines the conditions whereby an asset stranding program may produce higher future tariffs in any event. ${ }^{15}$ Consequently, FERC Order 888 and full recovery was argued to be sound public policy, noting recovery mechanisms can be structured without distorting competition (Joskow, 1996a; Tye \& Graves, 1996).

\subsection{A normative economic and legal analysis of the regulatory compact}

Efficiency and equity arguments can however be used in reverse (Boyd, 1998). For example, while it is unfair to strand a regulator-approved investment, it is also unfair to recover excessive and misguided utility investments from customers (Maloney \& Sauer 1998). Monopoly utilities that argue for full recovery are over-relying on regulation (Brennan \& Boyd, 1998); and as Graffy \& Kihm (2014) observe, those monopoly utilities that do are frequently presiding over businesses characterised by extensive investment mistakes in retrospect.

A strict normative economic and legal analysis of the regulatory compact does not support full recovery of stranded assets as Rose (1996), Navarro (1996), Boyd (1998) and others ${ }^{16}$ explain. Consumers have not agreed to the implicit terms of a regulatory compact whereas utility investors signed up for risky returns (Maloney \& Sauer, 1998; Woo et al. 2003). The regulatory compact assumes regulators act as agents on behalf of consumers whereas a long historical line of economic literature explains why this is not necessarily the case (see Stigler,

\footnotetext{
${ }^{13}$ Michaels (1995) observes the use of "regulatory compact" formally appears in court and regulatory proceedings from 1983. Rose (1996) notes the notion of a regulatory bargain can be traced back to case law in the $19^{\text {th }}$ century (regarding railroad regulation). In his 1972 article, Myers (p78) describes an 'implicit contract' between investors and regulators.

${ }^{14}$ Although not directly relevant to Australia, there is a strand of literature that extends this one step further and classes such regulatory action as a violation of the US Constitution's Takings Clauses of the Fifth Amendment and its application to the states under the Fourteenth Amendment. See Baumol \& Sidak (1995), Rose (1996) or Graffy \& Kihm (2014) for further details.

${ }^{15}$ The financial economics logic of Crawford (2014) considers a zero recovery scenario which differs from a partial recovery scenario in which a RAB is fundamentally unsustainable - even to the most optimistic equity investor.

${ }^{16}$ See also McArthur (1998), Brennan \& Boyd (1997), Graffy \& Kihm (2014) and Simshauser (2017).
} 
1971; Posner, 1974; Peltzman, 1976). And because no written contract exists with consumers, anything not explicitly identified in regulation is immediately contentious (Brennan \& Boyd, 1997). As Rose (1996) and Boyd (1998) explain, the sub-clauses of a regulatory compact are matters for pure speculation and cannot be relied upon to justify all of the upside, and none of the downside, inherent in long term contracts. Beard et al. (2003) highlight that long term contracts always include clauses for contingencies, viz. price reopeners in circumstances when prices formed under a long-term contract breach certain limits or when Material Adverse Change clauses are triggered. A normative analysis of economics and law under conditions of long term contract ambiguity, which ipso facto exists with the regulatory compact, dictates that responsibility tends to fall on the party best able to adapt to the relevant circumstances. In the case of investment error and disruptive competition, it is difficult to argue this is entirely the consumer (Rose, 1996; Boyd, 1998; Simshauser, 2017). ${ }^{17}$

\section{$2.4 \quad$ Full vs Partial recovery of stranded assets}

The obligation to supply and other incumbent burdens are, prima facie, compelling arguments in favour of full recovery and in certain instances will apply to specific investments (Navarro, 1996). However, rarely do utilities flag the risks of large capital expenditures with policymakers and regulatory authorities. McArthur (1998) observes that in hindsight, the regulatory compact argument appears designed to conceal the virtually exclusive role monopoly utilities have in planning national energy infrastructure, and their role in encouraging regulated capital-intensive outcomes.

Ideal regulation forces utilities to operate at competitive levels of investment, price, output and profit with prices set so utilities earn a 'fair return' on investment (Myers, 1972). But regulatory powers to enforce fair returns have limits and do not extend to setting rates that result in positive utility returns, or utility solvency when a network is in decline due to the presence of disruptive competition. The public policy goal of economic regulation is not to protect monopoly utilities from competition but to protect consumers from monopoly prices (Pierce, 1984; Rose, 1996). As Graffy \& $\operatorname{Kihm}^{18}$ (2014, p26-27) explain:

...regulation and the fair return principle applies when a utility has monopoly power, not when it is besieged by disruptive competition that it is failing to navigate... If market values decline in response to successful competition, utilities cannot simply look to their regulators to undo the impact of fundamental changes in market forces...

A crucial tenet of utility regulation is the used and useful principle (Hoecker, 1987). ${ }^{19}$ Pierce (1984) explains the prudent investment test is a low bar and rarely used in its pure form because it would be unusual for utilities to make blatantly imprudent capital commitments. When prudent investment is combined with used and useful, excluding certain investments is based on an objective test rather than finding fault (McArthur 1998). ${ }^{20}$ Regulatory approval at the time of investment commitment does not, therefore, form a basis for full recovery.

\footnotetext{
${ }^{17}$ Boyd (1998) noted from an efficiency perspective, interpretation of implicit contractual obligations following an unspecified contingency should consider which party can best adapt to, or insure against, risks due to a costly future contingency (this should include considerations of moral hazard). Analyses of how courts and policymakers interpret duties in the franchise relationship with utilities does not mean stranded assets should be fully recovered. Both an analysis of precedent and an economic analysis of optimal contracting suggest partial recovery.

${ }^{18}$ Graffy \& Kihm were referring to the 1945 Market Streetcar case. In summary, the San Francisco Streetcar company was incurring losses at a monopoly tariff of $5 \mathrm{c}$ in the face of disruptive competition (viz. buses and cars). The firm sought, and regulator approved, tariff increases to $7 \mathrm{c}$. This exacerbated market share losses, demand plunged further, thus producing a Death Spiral. The regulator reduced tariffs to $6 \mathrm{c}$ and court proceedings were initiated. Market Streetcar lost the case and this key regulatory principle (i.e. no obligation to protect a firm from disruptive competition) was established.

${ }^{19}$ The 'used and useful ' principle can be traced back to a New York Public Service Commission decision in 1922 . Hoecker (1987, p.306 - citing N.Y. Pub. Serv. Comm'n 1922) notes the principle established was that ...Consumers should not pay in rates for property not presently concerned in the service rendered unless (1) conditions exist point to its immediate future use, or (2) unless the property is such that it should be maintained for reasonable emergency or substitute service... This latter condition clearly indicating reserve planning margins form part of the used and useful asset stock. See also D'souza \& Jacob, 2001).

${ }^{20}$ Rose (1996, p70) explains that if a regulatory framework were to rely on a 'pure' prudent investment test, then returns to stock and bond holders would be very low and commensurate with the low risk of stranding. Conversely, a 'pure' used and useful test would have substantially higher returns to equity and debt holders because they would face stranding risks with no compensation because it is embedded in the rate of return. In practice, most regulatory frameworks employ a combination of both.
} 
Regulators have neither the resources, nor responsibility, to create and guarantee investment plans, and cannot be expected to match the expertise and resources of utilities, nor come close to second-guessing what constitutes a prudent investment program (Navarro, 1996; Maloney \& Sauer, 1998; Douglas et al. 2009). Mistakes made by regulators approving apparently prudent investments are likely to be a contributing factor, not a primary cause of stranded assets and to say otherwise would be re-writing history (Pierce, 1984). Ultimately, the regulatory system leaves entrepreneurial decisions and capital management in the hands of utility management, not those of the regulator (Madian, 1997).

Economic arguments in favour of full recovery are constructed around the premise that network regulation has limited the ability of monopoly utilities from raising prices, and that asset stranding may ultimately inflate the cost of capital in future periods. But as Navarro (1996), Pagach \& Peace (2000) and Woo et al. (2003) have noted, risk-adjusted profits are earned by monopoly utilities; and while utility tariffs have been "capped" they have also been "floored" - in no unregulated industry do inept firms enjoy such a low probability of failure (Michaels, 1995). Pagach \& Peace (2000) and Martin (2001) explain that investors may have an initial adverse reaction to a policy of partial recovery but most will quickly discern the difference between bad historic investments and well-founded future investments. D'Souza \& Jacob (2000) analysed stock price movements of 18 listed utilities in the US that disclosed stranded assets in their annual accounts during the 1990s which found that investors did not anticipate full recovery prior to FERC Order 888 - anticipating on average only $76-77 \%$ recovery.

To be clear, there is no serious argument for zero recovery of stranded regulated monopoly assets (Pierce, 1984; Navarro, 1996; McArthur, 1998; Brennan \& Boyd, 1997; Beard et al. 2003; Simshauser, 2017). Some recovery is appropriate, especially where utilities have been compelled to invest as a result of regulation or policy mistakes (Baumol \& Sidak, 1995; Hirst \& Hadley, 1998; Boyd, 1998; D’Souza \& Jacob, 2001; Martin, 2001; Beard et al. 2003). At risk is the credibility of government policy - that is, providing stable rules for the market is an important function of policymakers and a pattern of random or capricious changes undermines the credibility of government (Hogan, 1994; Simshauser, 2017). As Kydland \& Prescott (1977) explain, firms respond predictably to dynamic inconsistency.

In Simshauser (2017) a series of asset stranding principles for regulated networks were outlined. The necessary condition for stranded assets was defined as a network in decline, and sufficient condition being non-negative cost growth. Under these conditions tariffs will become unstable and the regulatory framework will approach the limits of its design envelope. The principles also suggested that stranded assets are a case-by-case proposition (Joskow, 1996b; Hirst \& Hadley 1998).

In an asset stranding process, the recovery amount (\%) and the mechanism for recovery to be selected is important. And while there are many possible mechanisms, it is ultimately a policy choice, not an analytical determination (Simshauser, 2017). A defining characteristic of electricity is that, from a pricing perspective, it has no natural form with flow ( $\mathrm{kWh}$ ), stock $(\mathrm{kW})$, load volatility and customer numbers all being legitimate pricing mechanisms (Boiteux, 1956; Boiteux \& Stasi, 1952; Nelson \& Orton, 2013; Simshauser, 2016; Keay, 2016). Accelerated depreciation ${ }^{21}$ is also a potential mechanism along with supra-competitive prices (Martin, 2001), explicit surcharges (Beard et al. 2003), return of capital (Pierce, 1984) and securitised bond issues (Michaels, 1998; Pagach \& Peace, 2000; Martin, 2001; Ritschel \& Smestad 2003). ${ }^{22}$ In the present exercise we have opted for the latter.

\footnotetext{
${ }^{21}$ Crew \& Kleindorfer (1992) noted that in the presence of emerging technology there is limited time for regulators to take remedial action and that exposed assets can adopt more accurate depreciation methods. Depreciation methods have long been of interest to economists, dating at least as far back as Hotelling (1925). Under rate of return regulation, choice of depreciation method represents a key input to regulated prices and has a circular reasoning which materially affects how capital costs are recovered (Schmalensee, 1989; Burness \& Patrick 1992).

${ }_{22}$ Michaels (1998) explains that as a financing tool, securitisation can be traced back to 1977 and its intended effect in the stranded asset case is to lower the cost of capital of the recovery target. The first deployment of transition bonds in the electricity industry was in California, where it was used to strand approximately $\$ 10 \mathrm{bn}$ in generation assets and deliver $10 \%$ tariff
} 


\section{Regulated Monopoly Model}

In this article, we use the Regulated Monopoly Model which simulates a template regulated network utility once certain inputs have been defined (see also Simshauser, 2017). Outputs include the Annual Regulated Revenue Requirement, Tariffs, Profit \& Loss, Balance Sheet and Cash Flow Statements and credit ratios. Model resolution is annual data over a 20 -year window. Key assumptions (Table 1) are based on parameters typical of an Australian regulated monopoly but could be adjusted for any relevant jurisdiction.

\begin{tabular}{|c|c|c|c|c|c|c|}
\hline \multicolumn{4}{|c|}{ Table 1: } & \multicolumn{3}{|l|}{ Model Inputs } \\
\hline \multicolumn{2}{|l|}{ Financial Inputs $(t=1)$} & \multirow[b]{2}{*}{2.25} & \multirow[b]{2}{*}{$\%$} & \multirow{2}{*}{$\begin{array}{l}\text { Network Inputs }(t=1) \\
\text { Customer Numbers }\end{array}$} & \multirow[b]{2}{*}{1.5} & \multirow[b]{2}{*}{ million } \\
\hline CPI & $\pi$ & & & & & \\
\hline X Factor & $\mathrm{X}$ & 0.10 & $\%$ & Avg Household Load & 6,800 & $\mathrm{kWh}$ \\
\hline Remain. Asset Life & $l$ & 30 & Yrs & Total Residential Load & 10,025 & GWh \\
\hline Net Capital Exp. & $C$ & $\$ 200$ & M & Connections Growth pa & 1.6 & $\%$ \\
\hline Operating Exp. & $\theta$ & $\$ 300$ & M & New Households Load & 4,500 & kWh \\
\hline Transmission Chrg. & $\vartheta$ & $\$ 275$ & M & Energy Efficiency Effect & -0.5 & $\%$ \\
\hline Accounting Tax & $a \tau^{i}$ & 30 & $\%$ & Initial Solar PV Takeup & 2.7 & $\%$ \\
\hline Est. Cash Tax & $c \tau^{i}$ & 15 & $\%$ & Initial Batter Takeup & 2.7 & $\%$ \\
\hline Benchmark Gearing & $\mathrm{D}^{\mathrm{u}} / \mathrm{V}^{\mathrm{u}}$ & 60 & $\%$ & Initial EV Takeup & 2.7 & $\%$ \\
\hline Risk Free Rate & $R f$ & 2.90 & $\%$ & Solar Self Consumption & 3,064 & $\mathrm{kWh}$ \\
\hline Swap Rate & $R_{t}^{u}$ & 0.00 & $\%$ & Battery Self Consumption & 1,692 & $\mathrm{kWh}$ \\
\hline BBB Credit Spread & $\mathrm{S}^{\mathrm{u}}$ & 219 & bps & EV Consumption & 2,700 & kWh \\
\hline Market Returns & $R m$ & 9.40 & $\%$ & Own-Price Elasticity & -0.10 & \\
\hline Equity Beta & $\beta u$ & 0.70 & $\%$ & Base/Park Scenario Elasticity & -0.10 & \\
\hline Bond Coupon & $I^{i}$ & 2.25 & $\%$ & Network / Retail Tariff & 40 & $\%$ \\
\hline Imputation Credits & $\gamma^{u}$ & 40 & $\%$ & +8 & & \\
\hline
\end{tabular}

In the present exercise, and as with Simshauser (2017), the regulated electricity distribution utility modelled has an opening RAB of $\$ 10$ billion, 1.5 million household customers, with existing households consuming on average $6,800 \mathrm{kWh}$ pa. Total residential load in the Base Case commences at $10,025 \mathrm{GWh}$ and decays each year, starting at $-0.7 \%$ and moderating to $0.3 \%$ through a combination of energy efficiency effects $(0.5 \%$ lost load pa), solar PV (per Figures 4-6) and battery take-up rates. New connections growth (1.6\%) results in new albeit smaller customers loads of $4,200 \mathrm{kWh}$ and in certain scenarios Electric Vehicle loads are added. Estimated own-price elasticity is -0.10 and given capital market in puts in Table 1, the benchmark WACC is $6.2 \%$ (see Eq.6).

\subsection{Annual Regulated Revenue Requirement}

For any network utility, the Annual Regulated Revenue Requirement $\left(A R_{t}^{i}\right)$ involves a building block approach comprising approved Operating Expenses $\theta_{t}^{i}$, Return of Capital (i.e. Regulatory Depreciation) $\delta_{t}^{i}$, Cash Taxes $c \tau_{t}^{i}$, Return on Capital $r_{t}^{i}$ and Transmission Use of System charges $\vartheta_{t}^{i}$ :

$A R_{t}^{i}=\sum\left(\theta_{t}^{i}, \delta_{t}^{i}, c \tau_{t}^{i}, r_{t}^{i}, \vartheta_{t}^{i}\right) \mid \delta_{t}^{i}=\left[\left(R A B_{t}^{i} / l_{t}^{i}\right)-\left(R A B_{t}^{i} \cdot \pi_{t}\right)\right]^{\wedge} r_{t}^{i}=\left(R A B_{t}^{i}\right) \cdot W A C C^{u}$

$\delta_{t}^{i}$ is derived through the combination of Straight-Line Depreciation $\left(R A B_{t}^{i} / l_{t}^{i}\right)$ where $\left(l_{t}^{i}\right)$ is average remaining useful asset life of the $i^{\text {th }}$ utility at time $t$, then deducting RAB Indexation $\left(R A B_{t}^{i} \cdot \pi_{t}\right)$ - the latter being how price inflation (viz. $\left.\pi_{t}\right)$ is accounted for in the sunk cost recovery process. $W A C C^{u}$ for electricity utility sector, $u$, is subsequently defined in Eq.(6). With Operating Expenses, $\forall t>1, \theta_{t}^{i}$ escalates at $C P I-X$.

reduction. As quantitative analysis later in this article demonstrate, the effectiveness of a securitisation program is contingent upon (i) interest rate differentials being greater than debt-tenor differences and (ii) where capital markets have systematically overestimated the risk of utility default on utility bond payments (Ritschel \& Smestad 2003). More directly, Michaels (1998, p60) notes that unless capital markets are wildly inefficient, securitization's effect on a utility's cost of capital is likely to be small. 
Each year $R A B_{t}^{i}$ is rolled-forward:

$R A B_{t+1}^{i}=\left[R A B_{t}^{i}+C_{t}^{i}+\left(R A B_{t}^{i} \cdot \pi_{t}\right)-\left(R A B_{t}^{i} / l_{t}^{i}\right)\right]$

In (2), $C_{t}^{i}$ is Net Capital Expenditure (i.e. capital expenditure less asset disposals) and $\left(\pi_{t}\right)$ is the inflation index. The non-linear tariff structures and quantities from the various network customer segments are given by $A R_{t}^{i}$ :

$A R_{t}^{i} \equiv \sum_{t=1}^{n} \sum_{j=1}^{m}\left(p_{t}^{k j} \cdot q_{t}^{k j}\right)$

Where $p_{t}^{k j}$ is the price of the $k^{t h}$ component of tariff $j$ in year $t$ and $q_{t}^{k j}$ is the relevant expected quantity of component $k$ of tariff $j$ in year $t$. Note the relevant quantity may be $\mathrm{kWh}, \mathrm{kW}$ or the number of days in year $t^{23}$

In order to derive underlying $A R_{t}^{i}$ for a Park and Loan scenario, let $\psi^{i}$ be the value of Parked Assets of the $i^{\text {th }}$ firm. Equation (1) is thus modified as follows:

$A R_{t}^{i}=\sum\left(\theta_{t}^{i}, \delta_{t}^{i}, c \tau_{t}^{i}, r_{t}^{i}, \vartheta_{t}^{i}\right) \mid r_{t}^{i}=\left(R A B_{t}^{i}-\psi^{i}\right) \cdot W A C C^{\wedge} \wedge \forall t$

Note $r_{t}^{i} \neq r_{t}^{i}$ due to a reduction in $R A B_{t}^{i}$ arising from $\psi^{i}$.

In order to derive headline $A R_{t}^{i}$ for Park and Loan scenario the recovery of Bonds must be accounted for. Let $b_{t}^{i}$ be the annual cash flows associated with Park and Loan Bonds issued of $\varphi^{i}$ with a tenor of $y$ years and coupon $I^{i}$ in order to finance the debt associated with Parked Asset amount $\psi^{i}$.

$A R_{t}^{i}=\sum\left(\theta_{t}^{i}, \delta_{t}^{i}, c \tau_{t}^{i}, r_{t}^{i}, \vartheta_{t}^{i}, b_{t}^{i}\right) \mid b_{t}^{i}=\left[\frac{\varphi_{t}^{i}}{\left[1-\left(1+I^{i}\right)^{-t} /\left(I^{i}\right)\right]}+\left(\varphi_{t}^{i} \cdot I^{i}\right)\right] \forall t \leq y \quad \varphi_{t}^{i}=\psi^{i} \cdot\left(\frac{D_{t}^{u}}{V_{t}^{u}}\right)$

Note that the terms $D_{t}^{u}$ and $V_{t}^{u}$ are defined in Eq.(6).

\subsection{Cost of Capital}

A crucial input driving results in equations (1), (4) and (5) is the $W A C C^{u}$ for regulated utility firms $u$ :

WACC $^{u}=\left\{\left(\frac{E_{t}^{u}}{v_{t}^{u}}\right) \cdot\left(\frac{\left.R_{f}+\left[R_{m}-R_{f}\right) \cdot \beta^{u}\right]}{\left[1-c \tau_{t}^{i} \cdot\left(1-\gamma^{u}\right)\right]}\right)\right\}+\left\{\left(\frac{D_{t}^{u}}{v_{t}^{u}}\right) \cdot\left(R_{t}^{u}+S_{t}^{u}\right)\right\}$

Where:

$R_{f} \quad=$ Risk free rate of return

$R_{m} \quad=$ expected market return

$\beta^{u} \quad=$ equity beta for the regulated electricity utility firms $u$

$E_{t}^{u} \quad=$ sector benchmark value of equity

$D_{t}^{u} \quad=$ sector benchmark value of debt

$V_{t}^{u} \quad=$ total market value $=\left(E_{t}^{u}+D_{t}^{u}\right)$

$R_{t}^{u} \quad=$ reference interest rate (swap rate) in year $t$ of regulated utility firms $u$

$S_{t}^{u} \quad=$ credit spread given BBB credit ratings of regulated utility firms $u$ in year $t$

$c \tau_{t}^{i} . \quad=$ effective taxation rate for the $i^{t h}$ firm

$\gamma^{u} \quad=$ estimated utilization of imputation tax credits of regulated utility firms $u$

${ }^{23}$ Consequently, the unit price may be $\mathrm{c} / \mathrm{kWh}, \$ / \mathrm{kW}$ or $\mathrm{c} /$ day. 
Equation (6) is based on Sharpe (1964) and Lintner (1965) with modifications by Officer (1994) to deal with dividend imputation (for those jurisdictions with taxation systems incorporating imputation credits).

\subsection{Dynamic Financial Model}

In the Profit \& Loss Statements, Earnings Before Interest \& Tax $\left(E B I T_{t}\right)$ and implied Cash Earnings $\left(E B I T D A_{t}\right)$ are given by:

$$
E B I T_{t}=A R_{t}^{i}-\Sigma\left[\theta_{t}^{i},\left(R A B_{t}^{i} / l_{t}^{i}\right), \vartheta_{t}^{i}, b_{t}^{i}\right] \wedge E B I T D A_{t}=E B I T_{t}+\vartheta_{t}^{i}
$$

Net Profit After Tax $\left(N P A T_{t}\right)$ commences with $E B I T_{t}$ from which interest costs and accounting taxes $a \tau_{t}^{i}$ are deducted.

$$
N P A T_{t}=\left[E B I T_{t}-\left[D_{t}^{i} \cdot\left(R_{t}^{u}+S_{t}^{u}\right)\right]\right] \cdot a \tau_{t}^{i} \mid a \tau_{t}^{i}=30 \% \forall t
$$

Net Cash Flow in time $t\left(N C F_{t}\right)$ given by:

$$
\begin{aligned}
& \left.N C F_{t}=\left[E B I T D A_{t}-c \tau_{t}^{i}-\left[D_{t}^{i} \cdot\left(R_{t}^{u}+S_{t}^{u}\right)\right]-\rho_{t}^{i}-C_{t}^{i}-Y_{t}^{i}\right]\right] \rho_{t}^{i}= \\
& \frac{D_{t}^{i}}{\left[1-\left(1+\left(R_{t}^{u}+S_{t}^{u}\right)\right)^{-n} /\left(R_{t}^{u}+S_{t}^{u}\right)\right]}{ }^{\wedge} c \tau_{t}^{i}=\left[E B I T_{t}-\left[D_{t}^{i} \cdot\left(R_{t}^{u}+S_{t}^{u}\right)\right] \cdot 15 \% \forall t\right]
\end{aligned}
$$

$\rho_{t}^{i}$ is principle repayments on outstanding debt $D_{t}^{i}$ for the $i^{\text {th }}$ firm in time $t$, and $Y_{t}^{i}$ is dividends declared and paid to shareholders of the $i^{\text {th }}$ firm in year $t$ (dividends are paid in the year declared). All other variables are as described above. Note the model limits the running yield arising from ordinary dividends paid from surplus cash as follows:

if $\left(\varphi^{i} \geq 0\right), \forall z, y, Y_{t}^{i} / E_{t}^{i} \leq 4 \%$

The Balance Sheet comprises working capital $\omega_{t}^{i}$ which is modelled to match anticipated quarterly outlays associated with cash costs $\theta_{t}^{i}, \vartheta_{t}^{i}, D_{t}^{i} \cdot\left(R_{t}^{i}+S_{t}^{u}\right)$ and $\rho_{t}^{i}$. Fixed assets are set to $R A B_{t}^{i}$. While the value of Debt $D_{t}^{i}$ is initially set at the regulatory benchmark $\left(D_{t}^{i} / V_{t}^{i}\right)$, in subsequent years it provides the mechanism by which cash surpluses or deficits are absorbed:

$D_{t}^{i}=\left[R A B_{t}^{i} \cdot\left(D_{t}^{i} / V_{t}^{i}\right)\right]^{\wedge} D_{t+1}^{i}=\left(D_{t}^{i}-\rho_{t}^{i}-N C F_{t}+d \omega_{t}^{i}\right)$

In certain circumstances $\left(D_{t}^{i} / V_{t}^{i}\right)$ falls materially below benchmark due to a build-up of cash arising from the constraint in equation (10), a special dividend or return of capital $\left(K_{t}^{i}\right)$ is initiated in the following year, as follows:

$K_{t}^{i}=i f\left[\left(D_{t}^{i} / V_{t}^{i}\right)\right] \geq 55 \%, 0, R A B_{t}^{i} \cdot 5 \% \forall t$

Equity $E_{t}^{i}$ is calculated as:

$E_{t}^{i}=\left(\omega_{t}^{i}+R A B_{t+1}^{i}-D_{t}^{i}\right)$

The Model produces three financial and three credit ratios:

$\begin{array}{ll}\text { Return on Assets } & E B I T_{t} /\left(\omega_{t}^{i}+R A B_{t}^{i}\right) \\ \text { Return on Equity } & N P A T_{t} / E_{t}^{i} \\ \text { Running Div. Yield } & Y_{t}^{i} / E_{t}^{i}\end{array}$ 
Gearing

FFO/Debt

FCF/Debt

$$
D_{t}^{i} /\left(\omega_{t}^{i}+R A B_{t}^{i}\right)
$$$$
F F O_{t} / D_{t}^{i} \mid F F O_{t}^{i}=\left[E B I T D A_{t}-D_{t}^{i} \cdot\left(R_{t}^{u}+S_{t}^{u}\right)-c \tau_{t}^{i}\right]
$$$$
\left(F F O_{t}-C_{t}^{i}-d \omega_{t}^{i}\right) / D_{t}^{i}
$$

Base Case Results (Years 1-7 displayed) from the model are presented in Table 2. The basic format of Model Results includes Energy Sales, detailed Profit \& Loss, Cashflow, Balance Sheet and Ratios. The key results to note from the Base Case are Energy Sold (GWh), which declines from 10,025GWh to 9,280GWh by Year 7 and continues to decay through to Year 20. The Average Tariff, which rises from $13.4 \mathrm{c} / \mathrm{kWh}$ to $16.7 / \mathrm{kWh}$ is driven by the continual rise in Revenue $(\$ 1,347.6 \mathrm{~m}$ to $\$ 1,548.8 \mathrm{~m})$ and Total Assets $(\$ 10,220.1 \mathrm{~m}$ to $\$ 10,863.5 \mathrm{~m})$. Note throughout this period, the firm retains a BBB credit rating or better.

\section{ENERGY SALES \\ Energy Sold (GWh) \\ Fixed Rate (c/day) \\ Variable Rate (c/kWh) \\ Average Tariff (c/kWh) \\ Tariff Increase}

Table 2: $\quad$ Base Case Results (Years 1-7)

\begin{tabular}{|c|c|c|c|c|c|c|}
\hline Yr 1 & Yr 2 & Yr 3 & Yr 4 & Yr 5 & Yr 6 & Yr 7 \\
\hline 10,025 & 9,945 & 9,866 & 9,714 & 9,566 & 9,421 & 9,280 \\
\hline 0.49 & 0.50 & 0.50 & 0.50 & 0.51 & 0.51 & 0.51 \\
\hline 10.8 & 11.1 & 11.4 & 11.9 & 12.4 & 12.9 & 13.4 \\
\hline 13.4 & 13.9 & 14.3 & 14.9 & 15.5 & 16.1 & 16.7 \\
\hline & $3.1 \%$ & $3.3 \%$ & $4.0 \%$ & $3.9 \%$ & $3.9 \%$ & 3.8 \\
\hline
\end{tabular}

\section{PROFIT \& LOSS}

Network Revenue

Stranding Charge - Bond Is suance

Total Revenue

TUoS

Opex

Interest - Park \& Loan

Depreciation

EBIT

Interest

Taxation - Accounting

NPAT (Underlying)

Significant Item - Stranded Assets

Significant Item - Wrapped Bonds

NPAT (Statutory)

\section{CASH FLOW}

EBITDA + Interest Park \& Loan

Park \& Loan - Wrapped Bond Sales

Park \& Loan - Interest

Taxation - Cash

Debt - Interest

Debt - Principal

Capex

Dividends Limit: $4.0 \%$

Special Dividend

Net Cash Flow

\begin{tabular}{crrrrrr}
$\begin{array}{c}\$ 1,347.6 \\
\text { Not Used }\end{array}$ & $\$ 1,378.4$ & $\$ 1,411.9$ & $\$ 1,445.8$ & $\$ 1,479.8$ & $\$ 1,514.2$ & $\$ 1,548.8$ \\
\hline$\$ 1,347.6$ & $\$ 1,378.4$ & $\$ 1,411.9$ & $\$ 1,445.8$ & $\$ 1,479.8$ & $\$ 1,514.2$ & $\$ 1,548.8$ \\
$\$ 275.0$ & $\$ 280.9$ & $\$ 287.0$ & $\$ 293.1$ & $\$ 299.4$ & $\$ 305.9$ & $\$ 312.4$ \\
$\$ 300.0$ & $\$ 306.5$ & $\$ 313.0$ & $\$ 319.8$ & $\$ 326.6$ & $\$ 333.7$ & $\$ 340.8$ \\
Not Used & & & & & & \\
$\$ 333.3$ & $\$ 347.8$ & $\$ 363.7$ & $\$ 380.1$ & $\$ 397.0$ & $\$ 414.3$ & $\$ 432.1$ \\
\hline$\$ 439.3$ & $\$ 443.3$ & $\$ 448.3$ & $\$ 452.8$ & $\$ 456.8$ & $\$ 460.4$ & $\$ 463.4$ \\
$\$ 305.4$ & $\$ 301.7$ & $\$ 297.4$ & $\$ 292.6$ & $\$ 313.5$ & $\$ 307.5$ & $\$ 301.0$ \\
$\$ 40.2$ & $\$ 42.5$ & $\$ 45.3$ & $\$ 48.1$ & $\$ 43.0$ & $\$ 45.9$ & $\$ 48.7$ \\
\hline$\$ 93.73$ & $\$ 99.14$ & $\$ 105.59$ & $\$ 112.12$ & $\$ 100.35$ & $\$ 107.00$ & $\$ 113.69$ \\
Not Used & & & & & & \\
Not Used & & & & & & \\
\hline$\$ 93.7$ & $\$ 99.1$ & $\$ 105.6$ & $\$ 112.1$ & $\$ 100.3$ & $\$ 107.0$ & $\$ 113.7$
\end{tabular}

$\begin{array}{ccccccc}\begin{array}{c}\$ 772.6 \\ \text { Not } \text { Used }\end{array} & \$ 791.0 & \$ 812.0 & \$ 832.9 & \$ 853.8 & \$ 874.7 & \$ 895.5\end{array}$

Not Used

$\begin{array}{rrrrrrr}\$ 20.1 & \$ 21.2 & \$ 22.6 & \$ 24.0 & \$ 21.5 & \$ 22.9 & \$ 24.4 \\ \$ 305.4 & \$ 301.7 & \$ 297.4 & \$ 292.6 & \$ 313.5 & \$ 307.5 & \$ 301.0 \\ \$ 88.9 & \$ 93.4 & \$ 98.2 & \$ 103.2 & \$ 108.5 & \$ 114.0 & \$ 119.8 \\ \$ 200.0 & \$ 204.3 & \$ 208.7 & \$ 213.2 & \$ 217.8 & \$ 222.4 & \$ 227.2 \\ \$ 168.8 & \$ 175.6 & \$ 183.6 & \$ 191.7 & \$ 179.3 & \$ 187.4 & \$ 195.5 \\ \$ 0.0 & \$ 0.0 & \$ 0.0 & \$ 515.4 & \$ 0.0 & \$ 0.0 & \$ 527.5 \\ -\$ 10.6 & -\$ 5.2 & \$ 1.4 & -\$ 507.2 & \$ 13.3 & \$ 20.5 & -\$ 499.8\end{array}$

\section{BALANCE SHEET}

\begin{tabular}{|c|c|c|c|c|c|c|c|c|}
\hline Working Capital & $\$ 220.1$ & $\$ 225.1$ & $\$ 230.1$ & $\$ 235.3$ & $\$ 240.6$ & $\$ 246.0$ & $\$ 251.5$ & $\$ 257.2$ \\
\hline Stranding Recovery & not used & & & & & & & \\
\hline Fixed Assets & $\$ 10,000.0$ & $\$ 10,091.7$ & $\$ 10,204.3$ & $\$ 10,307.0$ & $\$ 10,399.1$ & $\$ 10,480.1$ & $\$ 10,549.3$ & $\$ 10,606.3$ \\
\hline Total Assets & $\$ 10,220.1$ & $\$ 10,316.7$ & $\$ 10,434.4$ & $\$ 10,542.3$ & $\$ 10,639.7$ & $\$ 10,726.1$ & $\$ 10,800.9$ & $\$ 10,863.5$ \\
\hline Debt Finance & $\$ 6,000.0$ & $\$ 5,926.6$ & $\$ 5,843.4$ & $\$ 5,749.1$ & $\$ 6,158.4$ & $\$ 6,042.0$ & $\$ 5,913.1$ & $\$ 6,298.8$ \\
\hline \multirow[t]{2}{*}{ Equity } & $\$ 4,220.1$ & $\$ 4,390.1$ & $\$ 4,591.0$ & $\$ 4,793.2$ & $\$ 4,481.3$ & $\$ 4,684.1$ & $\$ 4,887.8$ & $\$ 4,564.7$ \\
\hline & $\$ 10,220.1$ & $\$ 10,316.7$ & $\$ 10,434.4$ & $\$ 10,542.3$ & $\$ 10,639.7$ & $\$ 10,726.1$ & $\$ 10,800.9$ & $\$ 10,863.5$ \\
\hline
\end{tabular}

RATIOS

Return on Assets (underlying)

Return on Equity (headline)

Running Yield to Opening Equity

Gearing

FCF/Debt ('Modest Positive' $=B B B$

$\mathrm{FFO} / \mathrm{Debt}(>6 \%=\mathrm{BBB}-)$

Implied Credit Rating

$\begin{array}{rrrrr} & 4.3 \% & 4.2 \% & 4.3 \% & 4.3 \% \\ & 2.1 \% & 2.2 \% & 2.2 \% & 2.5 \% \\ 59 \% & 4.0 \% & 4.0 \% & 4.0 \% & 4.0 \% \\ 57.4 \% & 56.0 \% & 54.5 \% & 57.9 \% \\ 4.1 \% & 4.4 \% & 4.8 \% & 4.8 \% \\ 7.5 \% & 8.0 \% & 8.6 \% & 8.4 \% \\ & \text { BBB } & \text { BBB } & \text { BBB } & \text { BBB }\end{array}$

$4.3 \%$
$2.1 \%$
$4.0 \%$
$56.3 \%$
$4.9 \%$
$8.6 \%$
BBB

$\begin{array}{rr}4.3 \% & 4.3 \% \\ 2.2 \% & 2.5 \% \\ 4.0 \% & 4.0 \% \\ 54.7 \% & 58.0 \% \\ 5.3 \% & 5.4 \% \\ 9.2 \% & 9.1 \% \\ \text { BBB }+ & \text { BBB }+\end{array}$

\section{7}

0.51 3.4
6.7 
The policy dilemma facing this utility is the trajectory of Energy Sold and Average Tariffs, which is best illustrated through the full 20-Year outputs in Figure 7. Specifically, network load contracts from 10,025GWh to 7,935 GWh (RHS axis) while Average Tariff (LHS Axis) rises from $13.4 \mathrm{c} / \mathrm{kWh}$ to $25.0 \mathrm{c} / \mathrm{kWh}$ in nominal terms $(16.40 \mathrm{c} / \mathrm{kWh}$ in real terms).

\section{Figure 7: Base Case Energy Sold (GWh) and Average Tariff (c/kWh)}

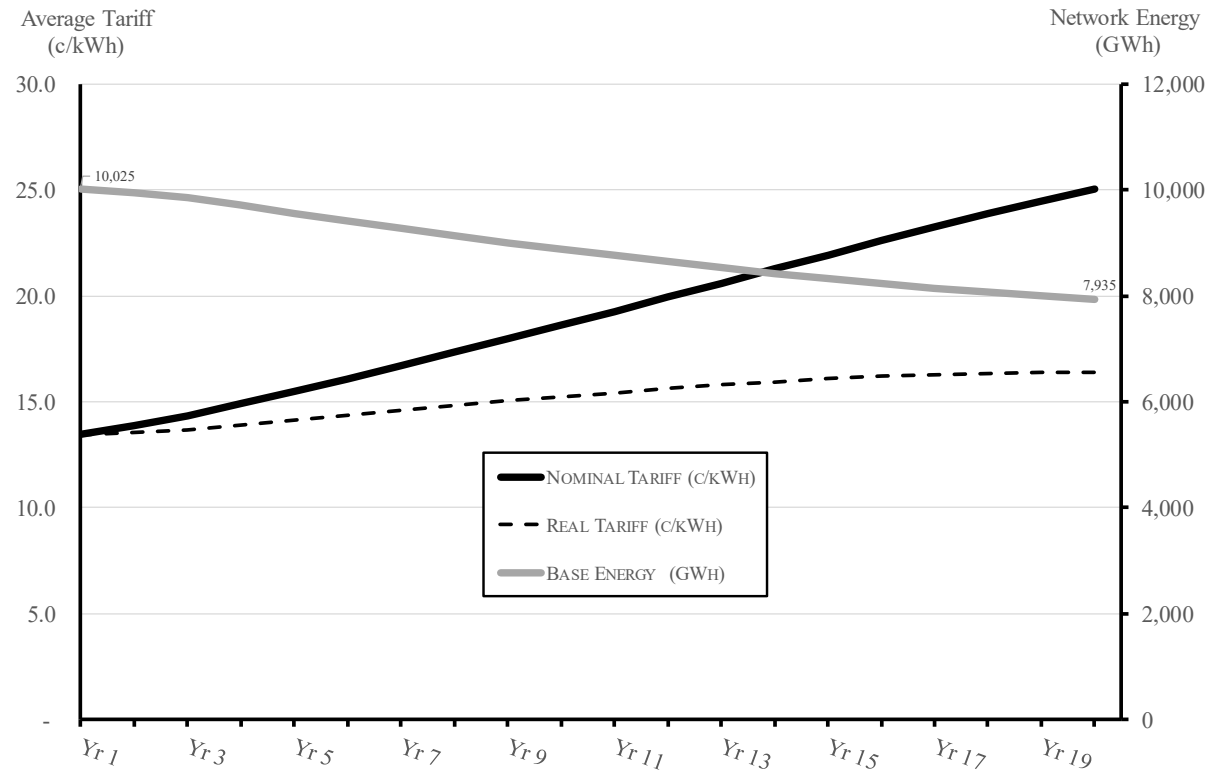

Recall the Year 1 network tariff is overinflated to begin with through a combination of Averch \& Johnson (1962) gold-plating - the product of policy error through a tightening of reliability standards, and an additional layer of investment mistakes in retrospect through demand forecast error and the implications of disruptive competition (i.e solar PV).

In order to derive an estimate of excess capacity, Figure 8 provides some context by presenting RAB by NEM region over the period 2001-2018 (LHS Axis) along with residential customer connections in each region (RHS Axis).

Figure 8: $\quad$ Regulated Asset Base vs Customer Connections: 2001-2018

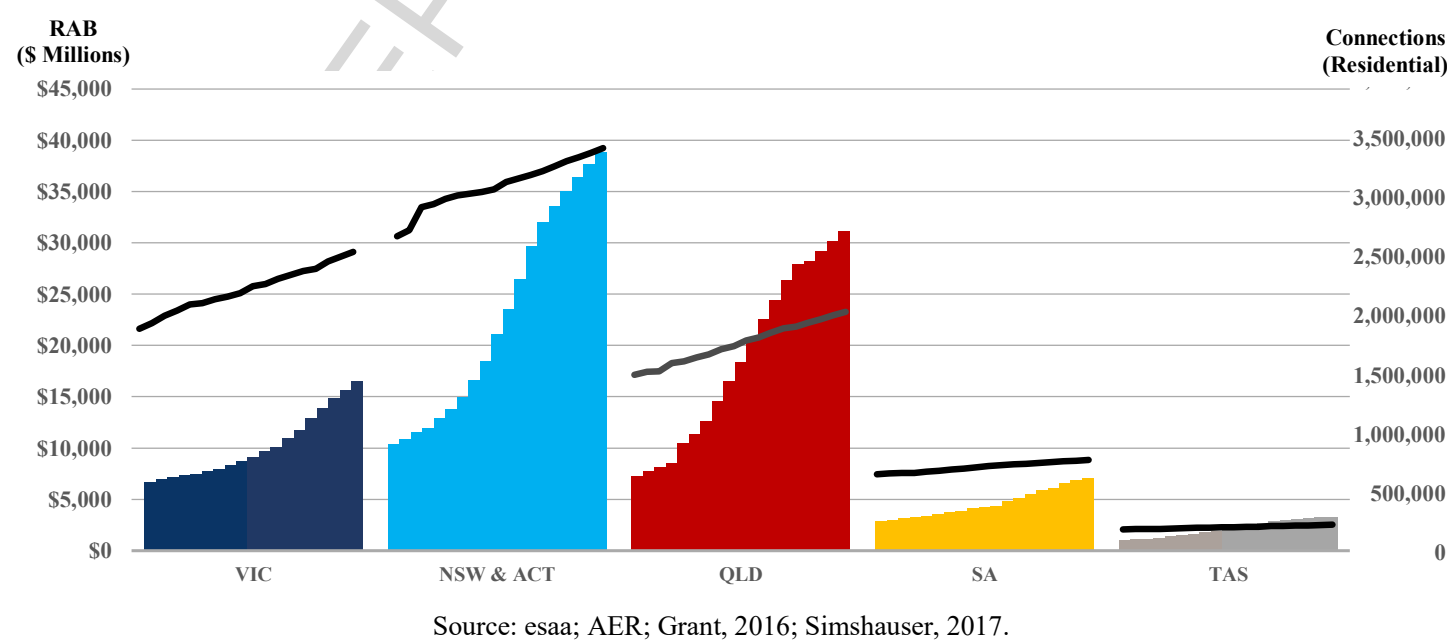

Table 3 takes the data from Figure 8 and presents an analysis of the change in network RABs per customer connection over the period 2005 to 2018 (with 2005 data inflated to 2018 \$'s using the Consumer Price Index). The combined RAB in 2005 was $\$ 49.8$ billion $(2018 \$)^{24}$, which serviced 7.47 million household accounts and a further 970,000 business customers.

${ }^{24}$ The $2005 \mathrm{RAB}$ was $\$ 35,768$ million in nominal terms. 
Combined Network RAB had risen to $\$ 93.7$ billion ( $+88 \%$ in real terms) by 2018 , whereas customer connections had only increased to 8.86 million (up 18.5\%). Consequently, RAB per connections had increased by $\$ 3,922(+59 \%$ in real terms). To the extent that this is considered an indicator of excess capacity, the final column in Table 3 implies the system is carrying an excess of $\$ 34,755$ million in network capital (see column J).

Table 3: $\quad$ Change in RAB, Customer Connections \& Excess RAB per Connection, 2005 to 2018

\begin{tabular}{|c|c|c|c|c|c|c|}
\hline \multirow[b]{2}{*}{ Region } & \multicolumn{3}{|c|}{2005 (in 2018 \$) } & \multicolumn{3}{|c|}{2018} \\
\hline & RAB & Connections & RAB/Connect & RAB & Connections & RAB/Connect \\
\hline A & B & $\mathrm{C}$ & $\mathrm{D}=(\mathrm{B} \div \mathrm{C})$ & E & $\mathrm{F}$ & $\mathrm{G}=(\mathrm{E} \div \mathrm{F})$ \\
\hline & (\$ Million) & (Customers) & (\$/Connect) & (\$ Million) & (Customers) & (\$/Connect) \\
\hline NSW & $\$ 18,021$ & $2,919,583$ & $\$ 6,173$ & $\$ 37,715$ & $3,337,844$ & $\$ 11,299$ \\
\hline QLD & $\$ 14,656$ & $1,574,167$ & $\$ 9,310$ & $\$ 30,209$ & $1,976,904$ & $\$ 15,281$ \\
\hline VIC & $\$ 10,428$ & $2,097,560$ & $\$ 4,971$ & $\$ 15,697$ & $2,533,147$ & $\$ 6,197$ \\
\hline SA & $\$ 4,747$ & 670,743 & $\$ 7,077$ & $\$ 6,875$ & 768,457 & $\$ 8,947$ \\
\hline TAS & $\$ 1,941$ & 213,832 & $\$ 9,077$ & $\$ 3,279$ & 245,012 & $\$ 13,383$ \\
\hline Total & $\$ 49,793$ & $7,475,885$ & $\$ 6,660$ & $\$ 93,776$ & $8,861,364$ & $\$ 10,583$ \\
\hline
\end{tabular}

\section{Change}

Region RAB/Connect RAB/Connect RAB Excess RAB Excess

\begin{tabular}{lcccc} 
& $\begin{array}{c}\mathrm{H}=(\mathrm{G}-\mathrm{D}) \\
(\$ / \text { Connect })\end{array}$ & $\begin{array}{c}\mathrm{I}=(\mathrm{H} \div \mathrm{D}) \\
(\%)\end{array}$ & $\begin{array}{c}\mathrm{J}=(\mathrm{H} \times \mathrm{F}) \\
(\$ \text { Million })\end{array}$ & $\begin{array}{c}(\mathrm{J} \div \mathrm{E}) \\
(\%)\end{array}$ \\
\hline NSW & $\$ 5,127$ & $83 \%$ & $\$ 17,112$ & $45 \%$ \\
QLD & $\$ 5,971$ & $64 \%$ & $\$ 11,804$ & $39 \%$ \\
VIC & $\$ 1,225$ & $25 \%$ & $\$ 3,103$ & $20 \%$ \\
SA & $\$ 1,870$ & $26 \%$ & $\$ 1,437$ & $21 \%$ \\
TAS & $\$ 4,306$ & $47 \%$ & $\$ 1,055$ & $32 \%$ \\
\hline Total & $\$ 3,922$ & $59 \%$ & $\$ 34,755$ & $37 \%$ \\
\hline
\end{tabular}

Source: Australian Bureau of Statistics (ABS), AER, esaa, Grant (2016), Simshauser (2017).

To be clear, this analysis does not account for important variables such as geographic spread, changes in customer density, peak load growth or growth in network 'hotspots' - and accounting for such variables would surely produce a different estimate. But it does provide some indication of the relative impact of erroneous policy vis-à-vis the tightening of reliability standards - which were applied to the NSW and QLD regions following blackouts in the two capital cities of Sydney and Brisbane, respectively.

With the sharp increase in network RABs, well above connections growth and energy demand, any objective test will conclude some level of capital will fail a used and useful test in the short run (especially in NSW and QLD). But the long run remains uncertain. After all, customer connections growth remains strong which tends to suggest the underlying network will remain used and useful (and perhaps the tariff design is a key source of the problem - see Simshauser 2016), In addition, a decline in system load over the long run is not a clear cut case given the alternate assumptions in Table 1 relating to Electric Vehicles (excluded from the Base Case). The NEM has 8.9 million residential electricity accounts, and 12.4 million motor vehicles ${ }^{25}$ (an average of 1.4 vehicles for each electricity account). These two parameters, (i) customer connections, and (ii) Electric Vehicles (EV) may require further clarity before determining that some component of the capital stock would permanently fail a used and useful test. Figure 9 presents three scenarios of final energy demand, (i) the Base Case which shows a network in decline (at $-1.2 \%$ per annum), (ii) the Park \& Loan Case which shows a limited opportunity scenario, and (iii) an EV scenario which shows a return to growth.

\footnotetext{
${ }^{25}$ See ABS series 9309, Motor Vehicle Census, Australia, 31 January 2018.
} 
Figure 9: $\quad$ Network Load under Base Case, Park and Loan Case and EV Scenario

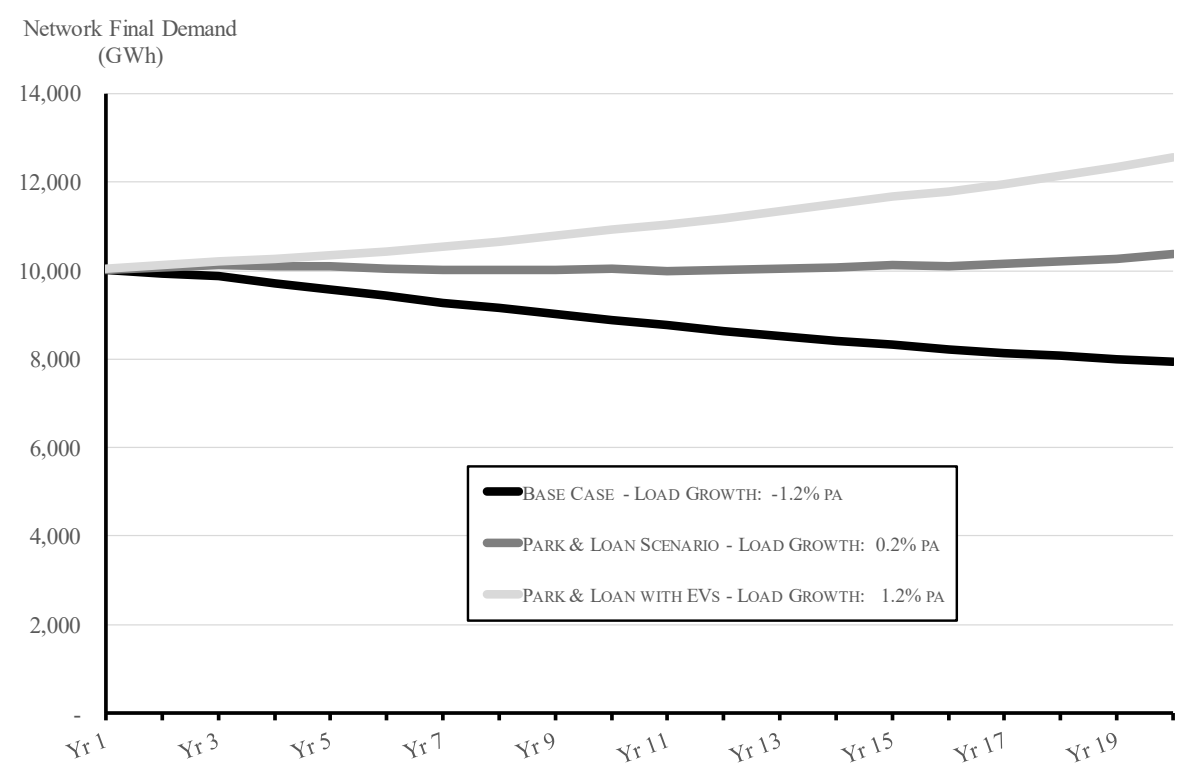

\section{Asset stranding under uncertainty - Park and Loan}

If the Base Case formed a dominant scenario, a policy decision to strand some component of the RAB would seem inevitable. The lower tariff arising from asset stranding would slow the rate of decline, reduce static efficiency losses, and reduce dynamic efficiency losses by curtailing over-investment in non-grid supply.

But because the present exercise involves demand uncertainty, network asset stranding may eventually prove to be an incorrect policy. Asset stranding is not a costless exercise. To the extent that equity capital and equity returns are adversely affected by such a policy, it would have ramifications for the future cost of capital and capital investment continuity.

Yet in the circumstances, excess capacity exists and is producing static and dynamic efficiency losses. An alternate policy instrument is to temporarily strand assets that fail a used and useful test, and progressively retest network utilisation at each regulatory reset (i.e. five-year intervals). In the following analysis, we use customer connections as the testing variable to maintain consistency with the method of determining excess capacity.

Specifically, basis for determining excess capacity and the level of RAB to be Parked, the following equation was used along with Queensland Data from Table 3 for illustrative purposes:

$$
\begin{aligned}
& \text { Parked_RAB } B_{t+2}^{\text {Qld }}=\left[\left(R A B_{2018}^{\text {Qld }} / \text { Cust }_{2018}^{\text {Qld }}\right)-\left(R A B_{2005}^{Q l d} / \text { Cust }_{2005}^{Q l d}\right) \cdot C P I_{2018} / C P I_{2005}\right] \cdot \\
& \text { Cust }{ }_{2018}^{\text {Qld }}
\end{aligned}
$$

The application of Eq.20 produced a result of $\$ 3,907$ million. Figure 10 provides a conceptual illustration of the network RAB before, and after, the Park and Loan Asset Stranding Policy. With the Park and Loan scenario, \$3,907 million of the RAB has been Parked in Year 2. This immediately reduces the RAB from $\$ 10,092$ million to $\$ 6,184$ million. ${ }^{26}$ Then at the end of each 5-year regulatory period, a certain amount of the Parked $\mathrm{RAB}$ has been returned-to-service (i.e. in Years 6,11 and 16) in line with customer connections growth.

\footnotetext{
${ }^{26}$ Note also that as with the modelling results in Simshauser (2017), annual Capex was reduced marginally, from $\$ 200$ million to $\$ 175$ million in recognition that such a policy will induce a change in forward investments.
} 


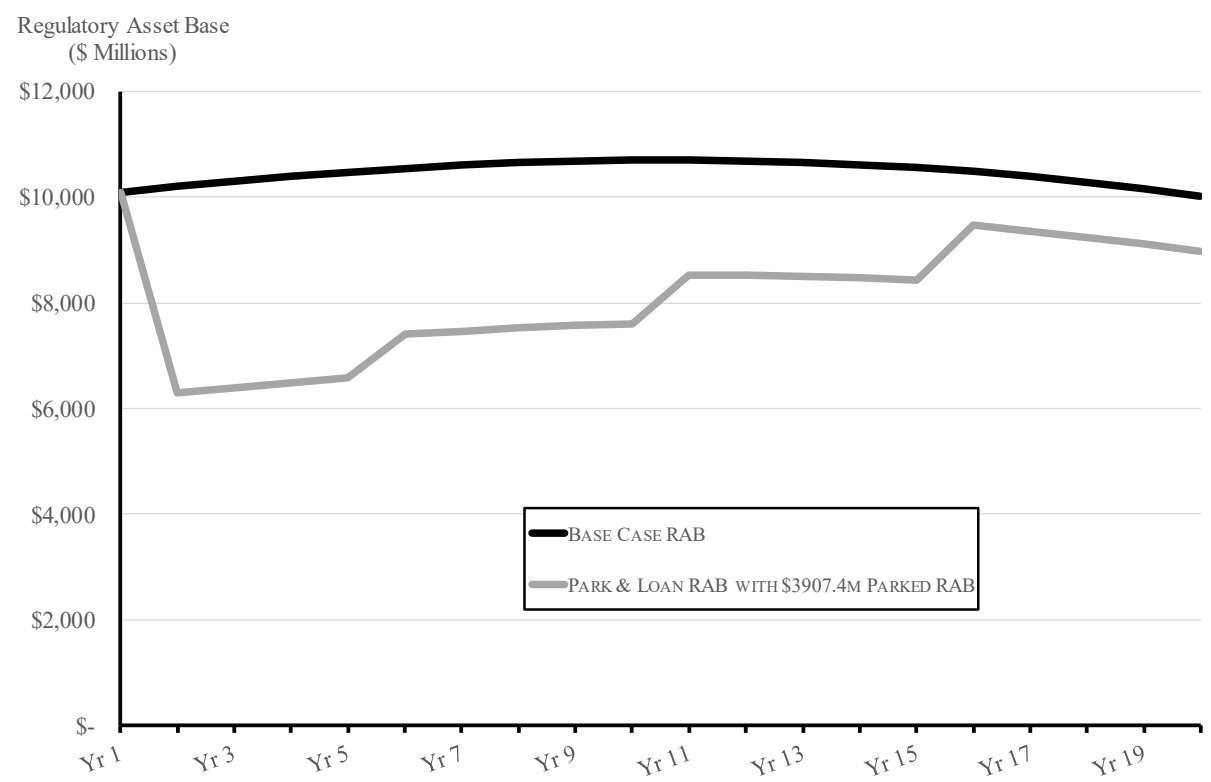

A policy decision to temporarily strand $\$ 3,907$ million or $\sim 39 \%$ of a network utility's RAB without some form of financial and economic reorganisation will produce a distressed business. The reason for this is axiomatic, but for clarity, the Model reveals that doing so results in utility financials and credit metrics immediately deteriorating from "investment grade" (i.e. BBB- or higher) to "junk". The firm would enter severe financial distress and would be technically insolvent within 12 months.

Our Park and Loan policy involves the securitisation of the benchmark debt associated with the Parked RAB. That is, $\$ 2,344$ million in credit-wrapped bonds (i.e. $60 \%$ of $\$ 3,907$ million) are issued and wrapped by government, with bond proceeds used to repay outstanding network utility debt strictly associated with the Parked RAB. This Park and Loan approach ensures utility credit metrics continue to meet investment grade thresholds. Furthermore, bonds can be wrapped by government because the beneficiaries of the policy, the 1.5 million household consumers, collectively underwrite bond coupon payments through specific Park \& Loan stranding charges. Table 4 presents the Park and Loan Model Results.

There are some vital changes to the financial and economic affairs of the network utility by comparison to the Table 3 Base Case results. First, notice from Year 2 in the Profit \& Loss Statement that Total Revenue $(\$ 1025.3 \mathrm{~m})$ now comprises both Network Revenue $(\$ 972.6 \mathrm{~m})$ and Stranding Charges $(\$ 52.7 \mathrm{~m})$ - the latter being a charge to consumers to cover the creditwrapped bond issue. Bond Interest also appears as a new expense item. The Profit \& Loss also includes two Significant Items:

1. a charge against profit for the Stranded Assets $(-\$ 3,907 \mathrm{~m})$ in Year 2 while in Year 6 (and in Years 11 and 16) as Parked RAB is progressively returned to service, an equivalent component of the Stranded Asset charge is reversed $(+\$ 763.6 \mathrm{~m}$ in Year 6, and in Years 11 and 16); and

2. proceeds from the sale of credit-wrapped bonds in Year $2(\$ 2,344.4 \mathrm{~m})$, while in Year 6 (and in Years 11 and 16) a charge against profit is applied for the redemption of the credit-wrapped bonds as Parked RAB is returned to service (and in consequence, proportional utility Debt Finance is resumed and underpinned by the reinstated RAB). 
Table 4: $\quad$ Park and Loan Scenario Results (Years 1-7)

\section{ENERGY SALES}

Energy Sold (GWh)

Fixed Rate (c/day)

Variable Rate (c/kWh)

Average Tariff (c/kWh)

Tariff Increase

\section{PROFIT \& LOSS}

Network Revenue

Stranding Charge - Bond Issuance

Total Revenue

TUoS

Opex

Interest - Park \& Loan

Depreciation

EBIT

Interest

Taxation - Accounting

NPAT (Underlying)

Significant Item - Stranded Assets

Significant Item - Wrapped Bonds

NPAT (Statutory)

\section{CASH FLOW}

EBITDA + Interest Park \& Loan

Park \& Loan - Wrapped Bond Sales

Park \& Loan - Interest

Taxation - Cash

Debt - Interest

Debt - Principal

Capex

Dividends Limit: $4.0 \%$

Special Dividend

Net Cash Flow

Yr

$\begin{array}{rrrrrrr}\text { Yr 1 } & \text { Yr 2 } & \text { Yr 3 } & \text { Yr 4 } & \text { Yr 5 } & \text { Yr 6 } & \text { Yr 7 } \\ & & & & & & \\ 10,025 & 10,070 & 10,120 & 10,102 & 10,096 & 10,038 & 10,022 \\ 0.49 & 0.35 & 0.35 & 0.36 & 0.36 & 0.39 & 0.40 \\ 10.8 & 7.7 & 7.9 & 8.2 & 8.4 & 9.3 & 9.6 \\ 13.44 & 10.18 & 10.41 & 10.72 & 10.97 & 12.08 & 12.40 \\ & -24.3 \% & 2.3 \% & 2.9 \% & 2.4 \% & 10.0 \% & 2.7 \%\end{array}$

\begin{tabular}{rrrrrrr}
$\$ 1,347.6$ & $\$ 972.6$ & $\$ 1,001.1$ & $\$ 1,030.2$ & $\$ 1,055.1$ & $\$ 1,169.7$ & $\$ 1,200.5$ \\
$\$ 0.0$ & $\$ 52.7$ & $\$ 52.7$ & $\$ 52.7$ & $\$ 52.7$ & $\$ 42.4$ & $\$ 42.4$ \\
\hline$\$ 1,347.6$ & $\$ 1,025.3$ & $\$ 1,053.9$ & $\$ 1,083.0$ & $\$ 1,107.9$ & $\$ 1,212.1$ & $\$ 1,243.0$ \\
$\$ 275.0$ & $\$ 198.2$ & $\$ 203.5$ & $\$ 208.9$ & $\$ 213.5$ & $\$ 236.3$ & $\$ 242.2$ \\
$\$ 300.0$ & $\$ 306.5$ & $\$ 313.0$ & $\$ 319.8$ & $\$ 326.6$ & $\$ 333.7$ & $\$ 340.8$ \\
$\$ 0.0$ & $\$ 52.7$ & $\$ 52.7$ & $\$ 52.7$ & $\$ 52.7$ & $\$ 42.4$ & $\$ 42.4$ \\
$\$ 333.3$ & $\$ 213.1$ & $\$ 224.1$ & $\$ 235.6$ & $\$ 247.5$ & $\$ 290.0$ & $\$ 303.4$ \\
\hline$\$ 439.3$ & $\$ 254.8$ & $\$ 260.5$ & $\$ 266.0$ & $\$ 267.5$ & $\$ 309.7$ & $\$ 314.2$ \\
$\$ 305.4$ & $\$ 182.3$ & $\$ 177.9$ & $\$ 194.6$ & $\$ 195.0$ & $\$ 195.1$ & $\$ 215.0$ \\
$\$ 40.2$ & $\$ 21.7$ & $\$ 24.8$ & $\$ 21.4$ & $\$ 21.7$ & $\$ 34.4$ & $\$ 29.7$ \\
\hline$\$ 93.7$ & $\$ 50.7$ & $\$ 57.8$ & $\$ 50.0$ & $\$ 50.7$ & $\$ 80.2$ & $\$ 69.4$ \\
$\$ 0.0$ & $-\$ 3,907.4$ & $\$ 0.0$ & $\$ 0.0$ & $\$ 0.0$ & $\$ 763.6$ & $\$ 0.0$ \\
$\$ 0.0$ & $\$ 2,344.4$ & $\$ 0.0$ & $\$ 0.0$ & $\$ 0.0$ & $-\$ 458.1$ & $\$ 0.0$ \\
\hline$\$ 93.7$ & $-\$ 1,512.2$ & $\$ 57.8$ & $\$ 50.0$ & $\$ 50.7$ & $\$ 385.6$ & $\$ 69.4$
\end{tabular}

\section{BALANCE SHEET}

\begin{tabular}{|c|c|c|c|c|c|c|c|c|}
\hline Working Capital & $\$ 220.1$ & $\$ 225.1$ & $\$ 230.1$ & $\$ 235.3$ & $\$ 240.6$ & $\$ 246.0$ & $\$ 251.5$ & $\$ 257.2$ \\
\hline Stranding Account & & $\$ 0.0$ & $-\$ 3,907.4$ & $\$ 0.0$ & $\$ 0.0$ & $\$ 0.0$ & $\$ 763.6$ & $\$ 0.0$ \\
\hline Fixed Assets & $\$ 10,000.0$ & $\$ 10,091.7$ & $\$ 6,289.1$ & $\$ 6,389.0$ & $\$ 6,483.8$ & $\$ 6,572.7$ & $\$ 7,406.0$ & $\$ 7,468.0$ \\
\hline Total Assets & $\$ 10,220.1$ & $\$ 10,316.7$ & $\$ 6,519.2$ & $\$ 6,624.3$ & $\$ 6,724.3$ & $\$ 6,818.7$ & $\$ 7,657.5$ & $\$ 7,725.2$ \\
\hline Debt Finance & $\$ 6,000.0$ & $\$ 5,926.6$ & $\$ 3,494.9$ & $\$ 3,823.8$ & $\$ 3,831.4$ & $\$ 3,834.0$ & $\$ 4,224.2$ & $\$ 4,178.4$ \\
\hline \multirow[t]{2}{*}{ Equity } & $\$ 4,220.1$ & $\$ 4,390.1$ & $\$ 3,024.2$ & $\$ 2,800.5$ & $\$ 2,892.9$ & $\$ 2,984.7$ & $\$ 3,433.3$ & $\$ 3,546.8$ \\
\hline & $\$ 10,220.1$ & $\$ 10,316.7$ & $\$ 6,519.2$ & $\$ 6,624.3$ & $\$ 6,724.3$ & $\$ 6,818.7$ & $\$ 7,657.5$ & $\$ 7,725.2$ \\
\hline \multicolumn{9}{|l|}{ RATIOS } \\
\hline \multicolumn{2}{|c|}{ Return on Assets (underlying) } & $4.3 \%$ & $3.9 \%$ & $3.9 \%$ & $4.0 \%$ & $3.9 \%$ & $4.0 \%$ & $4.1 \%$ \\
\hline \multicolumn{2}{|c|}{ Return on Equity (headline) } & $2.1 \%$ & $-50.0 \%$ & $2.1 \%$ & $1.7 \%$ & $1.7 \%$ & $11.2 \%$ & $2.0 \%$ \\
\hline \multicolumn{2}{|c|}{ Running Yield to Opening Equity } & $4.0 \%$ & $0.1 \%$ & $4.0 \%$ & $4.0 \%$ & $4.0 \%$ & $4.0 \%$ & $4.0 \%$ \\
\hline Gearing & $59 \%$ & $57.4 \%$ & $53.6 \%$ & $57.7 \%$ & $57.0 \%$ & $56.2 \%$ & $55.2 \%$ & $54.1 \%$ \\
\hline \multicolumn{2}{|c|}{ FCF/Debt ('Modest Positive' $=$ BBB-) } & $4.1 \%$ & $4.1 \%$ & $4.2 \%$ & $4.1 \%$ & $4.3 \%$ & $5.4 \%$ & $5.4 \%$ \\
\hline \multicolumn{2}{|c|}{$\mathrm{FFO} /$ Debt $(>6 \%=B B B-)$} & $7.5 \%$ & $9.4 \%$ & $9.1 \%$ & $9.1 \%$ & $9.4 \%$ & $10.2 \%$ & $10.3 \%$ \\
\hline \multicolumn{2}{|c|}{ Implied Credit Rating } & BBB & $\mathrm{BBB}+$ & $\mathrm{BBB}+$ & $\mathrm{BBB}+$ & $\mathrm{BBB}+$ & $\mathrm{BBB}+$ & $\mathrm{BBB}+$ \\
\hline
\end{tabular}

Similar movements then flow through the Cash Flow Statement and the Balance Sheet.

Notice the firm retains its investment grade credit metrics. However, in this particular version of the model, the equity component of the Parked RAB is stranded without compensation until such time as it is returned-to-service. Equity return variations of the model are of course possible, and in certain instances, warranted.

Figure 11 illustrates the annual balance of the Parked RAB (both underlying Parked RAB, and headline Parked RAB which includes Indexation consistent with Eq.2) and wrapped Bonds on issue along with their redemption profile. While not evident from Table 4, Figure 11 also highlights that Bonds are fully redeemed in Year 21, wheras some residual Parked $\mathrm{RAB}$ equity remains outstanding. 
Figure 11: Parked RAB and Wrapped Bonds on Issue

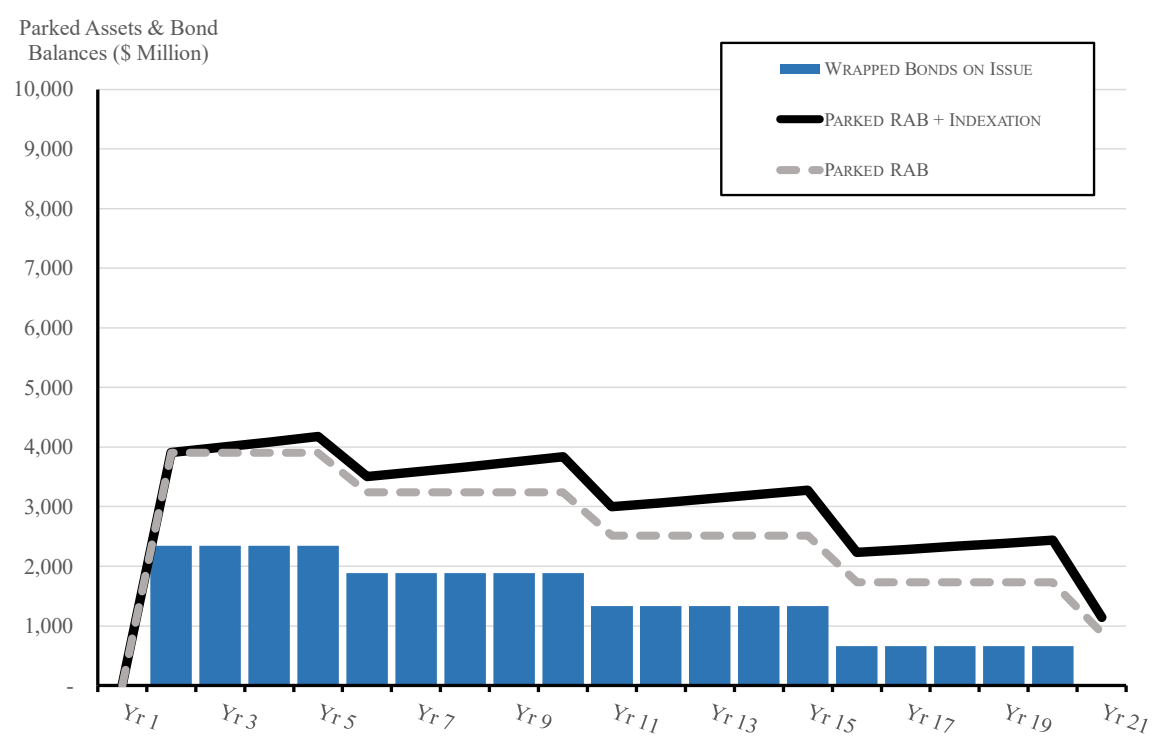

The effect of the Parked RAB and securitised bond issue is an immediate and pronounced reduction in network tariffs, as Figure 12 illustrates. Recall that the continuously rising Base Case tariff was driven by a rising RAB and contracting load. In the present model, the immediate reduction in the RAB produces a lower Park and Loan tariff, and when combined with modest own-price and inter-scenario demand elasticity assumptions (i.e. - 0.10 , and $40 \%$ thereof due to network tariffs forming only $40 \%$ of the final electricity bill), the rate of network load in decline slows. Note however there are pronounced tariff rises as components of the Parked RAB are gradually returned-to-service.

Figure 12 also includes a third scenario involving the Park \& Loan structure but with the addition of EVs. The material expansion in network load (per Figure 9) produces a lower tariff due to better utilisation of the sunk network, albeit with pronounced rises in tariffs as components of the Parked RAB are returned-to-service.

Figure 12: Base Case tariffs vs Park and Loan tariffs

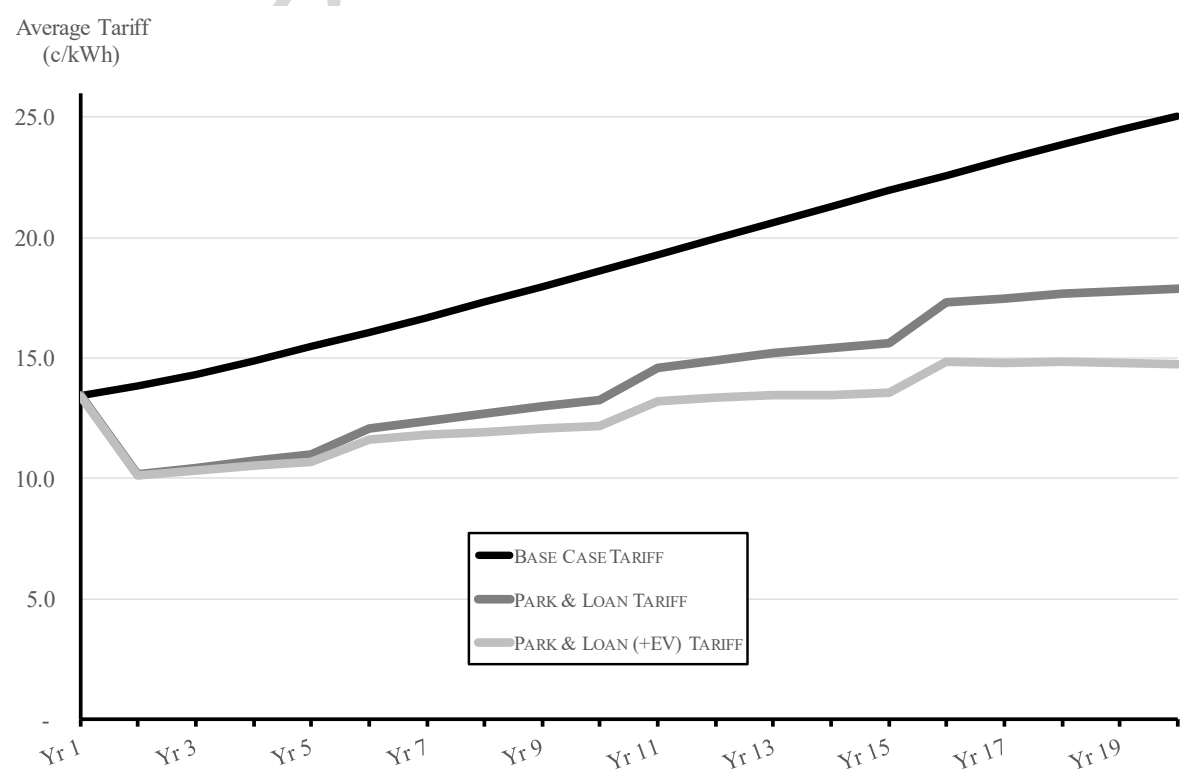

The results in Figure 12 are based on a simplified variable rate tariff. A variable rate structure $(\mathrm{c} / \mathrm{kWh})$ is a poor design for an electricity network given periodic load and intermittent solar PV (see Simshauser 2016). As noted earlier, backup services are greatly undervalued by two- 
part tariffs let alone a single rate tariff structure. To examine the other extreme of pricing structures would be a fixed connection charge (\$ per connection per annum) for each customer. This is illustrated in Figure 13, and the same substantive result prevails, namely, a sharp initial reduction in the price of network services, with gradual step-ups as some component of the Parked RAB is returned-to-service. ${ }^{27}$

Figure 13: Base Case Connection Charge vs Park and Loan Connection Charge

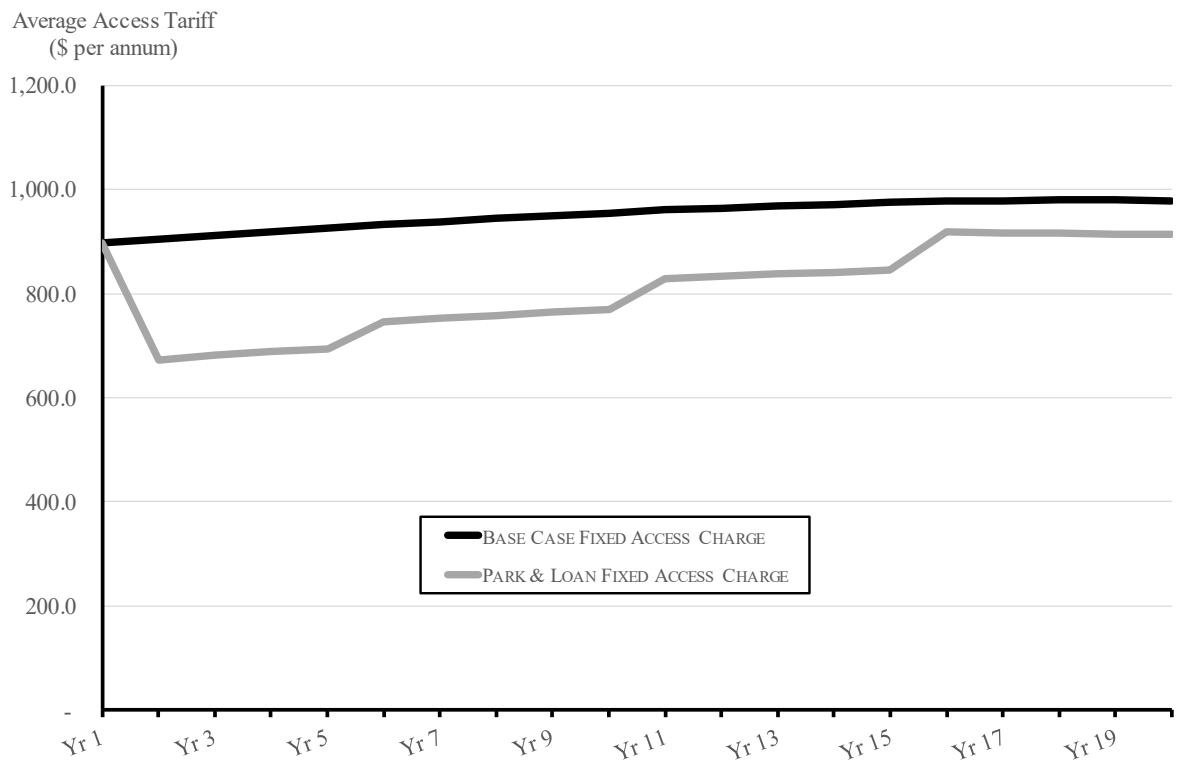

While a variable rate tariff is a sub-optimal tariff design by comparison to a two-part tariff, a pure connection access charge is also likely to be suboptimal. The ideal tariff design likely to comprise some combination of fixed access, maximum demand charge and variable energy rate (Simshauser, 2016).

\section{Policy discussion}

The advantages of a Park \& Loan policy are an immediate reduction in the RAB, a utility that maintains its credit metrics, a material and sustained reduction in network tariffs, and bypass at more efficient levels. Above all, the uncertainty of future demand is dealt with through the option value of time - Parked Assets are returned to service in line with connections growth. But we have dealt seldom and lightly with its disadvantages, including matters of implementation and the opportunity cost of such a policy.

\subsection{Impact of a government credit wrap: government fiscal constraints}

The first implementation matter relates to the use of government-wrapped bonds in the transaction process. Network utilities are among the most capital-intensive businesses in any modern economy, and a material Park \& Loan policy event diverts some level of scarce balance sheet capacity of government.

How a 'Park \& Loan' policy might impact government finances depends on how such a transaction is structured. From a transaction perspective, the use of credit-wrapped or securitised bonds to finance an asset stranding is not a novel concept; during the 1990s securitised bonds were issued and repaid over time by Californian electricity consumers as a part of their asset stranding activities under FERC Order $888 .{ }^{28}$

\footnotetext{
${ }^{27}$ Note in the Regulated Monopoly Model EVs do not add to customer connections, hence the EV scenario is the same as the Parked RAB scenario vis-à-vis fixed connection charge.

${ }^{28}$ In an analogous scenario, the State of New South Wales issued $\$ 700$ million in government bonds to underwrite a collapsed building construction insurer (i.e. a subsidiary of HIH Insurance) that was important to the continuity of the State's building construction industry, and in the view of policymakers at the time, crucial to the continuity of the State's macro economy. A hypothecated tax on building insurance policies was legislated, which ensured the State's balance sheet and credit rating were largely unaffected. The associated liabilities were redeemed over a 12-year period via the hypothecated tax.
} 


\subsection{Taxpayer residual risk}

Under any Park \& Loan scenario, some risk of permanent asset stranding must exist. A considerable level of professional judgement is therefore required in determining the suitability of such a policy for a given network utility. In our view, an overcapitalised metropolitan network, with an already high market share of solar PV, extensive imbalances between consumer loads and solar PV production (per Figure 6), steady growth in consumer connections (per Figure 8) and currently low uptake of electric vehicles would seem more suited to the possibility of a Park \& Loan policy than a rural/remote network in which disconnecting from the grid via non-trivial investment solar and battery storage is becoming an increasingly viable alternative. Furthermore, a publicly owned network (i.e. with common consumers and taxpayers) would present a lower recovery risk than a private or publicly listed network - distributional effects notwithstanding ${ }^{29}$.

\subsection{Utility incentives vs. moral hazard after a Park \& Loan stranding event}

In our Park \& Loan stranding event, we reorganised the balance sheet of a network utility by refinancing the stranded debt through credit-wrapped bonds with recovery via a consumer stranding charge, thus ensuring an investment grade credit rating is maintained. We did not deal with stranded equity - noting that recovery could span the range of $0-100 \%$ subject to circumstances and policy objectives. An issue for policymakers is that $0 \%$ recovery may result in the hold-up of much-needed investment in "network hotspots", whereas $100 \%$ recovery provides little incentive to avoid a repeat episode of significant investment mistakes. How the former is best dealt with is through each regulatory determination - with reliability of supply performance metrics (as is commonly the case) forming part of the overall revenue, while the latter is best dealt with by ensuring equity recovery is only partial for the reasons outlined in Section 2.

\subsection{Impact of a Park \& Loan on future WACC rulings}

Prima facie, a stranding event may result in an elevated cost of capital for future investment. However, inherent in the design of the Park \& Loan policy is an objective of ensuring debt investors are left neutral following a stranding event - specifically to minimise any impacts on the future cost of debt.

How equity capital markets respond will tie directly with the recovery level of stranded equity (i.e. $0-100 \%$ ). However, recall from Section 2 that while equity investors may have an initial adverse reaction to a stranding event, most will quickly discern the difference between bad historic investments and well-founded future investments (Pagach \& Peace, 2000; Martin, 2001; Simshauser, 2017). A stranding policy may well benefit from a coincident shift from a Regulated Revenue Cap to a Regulated Average Price Cap; if utilities are to be exposed to the (downside) risk of lower demand, they should also be exposed to the (upside) risk of higher demand - and this should help eliminate any pressure to inflate the WACC.

\subsection{Asset Stranding: recovery vs. write-off}

The final matter which is not explicitly addressed in our Park \& Loan policy is the appropriate level of stranded asset recovery. In our analysis, we were silent on the matter of stranded equity and therefore by omission ( $c f$ by design) $40 \%$ of stranded assets were written off (i.e. recall $60 \%$ of the RAB was debt financed, and $40 \%$ equity financed). Our Review of Literature revealed that there is no credible case for a $100 \%$ write-off of regulated network assets due to the burdens of incumbency (see Section 2.3), but neither was there a case for full recovery; in other words, in an asset stranding program some level of assets will be written off.

\footnotetext{
${ }^{29}$ While public ownership means consumers and taxpayers form the same group, the incidence of cost recovery will of course be vastly different.
} 
In Simshauser (2017), the matter of recovery was dealt with directly and according to certain policy objectives and constraints, viz. i). network utility solvency, ii). meeting certain credit metrics; iii). achieving allocative efficiency vis-à-vis network tariff levels; and iv). network tariff stability. The result was a $71.6 \%$ stranded asset recovery rate (i.e. with $28.4 \%$ of stranded assets written off). However, a key conclusion from the analysis was that such results arise from policy choices, not analytical determinations. Policies and their applicability were also argued to be assessed on a case-by-case basis; a regional grid will face greater challenges (and lower recovery rates) than a metropolitan grid, with the so-called 'edge of grid' likely to recede over time due to changes in technology.

\section{Conclusion}

From 2004 to 2018 the Regulatory Asset Base of electricity networks in Australia's National Electricity Market tripled in value, from $\$ 32$ billion to $\$ 93$ billion following a misguided policy of tighter reliability standards, erroneous load forecasts and significant investment mistakes in retrospect. Not only did demand growth fail to materialise, load contracted over the period 2010-2015. The rising RAB, contracting demand and regulated revenue constraint produced sharply rising network tariffs. Various consumer groups and regulatory bodies argued that assets should be stranded (with zero recovery) and network tariffs reduced.

A change in network tariff trajectory did occur from 2015, not through asset stranding, but courtesy of record low interest rates, low and stable inflation rates, and a consequential (and severe) reduction in the regulated rate of return awarded to networks by the Australian Energy Regulator. The regulated rate of return for networks in 2009 for the 2010-2015 regulatory period was $10.06 \%$ following the Global Financial Crisis; this was reduced to just $6.01 \%$ in the 2015-16 determination - a reduction of 405 basis points. ${ }^{30}$ From 2015-2018, final electricity demand increased once again across various networks - a reminder that network demand is inherently uncertain.

In this article, we presented a method for dealing with stranded assets under uncertainty. Rather than permanently stranding assets that fail a used and useful test, we temporarily Parked the excess network RAB and proceeded to reorganise the financial and economic affairs of a template network utility by issuing credit-wrapped bonds to finance the debt associated with the stranded capital stock. Our policy then re-tested the Parked RAB at the end of each five-year regulatory determination. Parked Assets were Un-Parked and returnedto-service in line with customer connections growth. The policy produced an immediate reduction in network tariffs and a more stable trajectory albeit with marked increases when assets were returned-to-service.

However, the policy is not without costs or risks. A Park \& Loan policy diverts government balance sheet capacity, transfers recovery risk to taxpayers, and varying levels of stranded equity recovery may create perverse incentives relative to policymaker objectives.

Consequently, and as we noted at the outset, our policy prescription shows what can be done, not necessarily what should be done vis-à-vis excess network capacity.

Above all, our analysis dealt seldom and lightly with the treatment of Parked equity capital and how to treat a Parked RAB that, in time, proves to be permanently stranded. These remain areas for further research.

\footnotetext{
${ }^{30}$ See AER determinations at https://www.aer.gov.au/networks-pipelines/determinations-accessarrangements? $\% 55 \mathrm{~B} 0 \% 5 \mathrm{D}=$ field_accc_aer_sector $\% 3 \mathrm{~A} 4$ The regulated rate of return data in this instance refers to Energex determinations.
} 


\section{References}

ACCC: Australian Competition \& Consumer Commission, (2018), "Restoring electricity affordability and Australia's competitive advantage", Retail electricity pricing inquiry - final report, Commonwealth of Australia, Canberra.

Averch, H. and Johnson, L. (1962), "Behaviour of the firm under regulatory constraint", American Economic Review, 52(1): 1052-1069.

Baumol, W. \& G. Sidak (1995). "Stranded Costs", Harvard Journal of Law and Public Policy, 18(3): 835-49.

Beard, T., Kaserman, D. and Mayo, J., (2003), "Regulation, competition, and optimal recovery of stranded costs", International Journal of Industrial Organization, 21(2003): 831-848.

Boiteux, M. (1956), “La vente au cout marginal”, Revue Francaise de L'Energie, 8(81): 113-117. Translated in Nelson, J. 1964, "The determination of costs of expansion of an interconnected system of production and distribution of electricity", Marginal Cost Pricing in Practice, Prentice Hall Inc, Englewood Cliffs.

Boiteux, M. \& Stasi, P. (1952), "Sur la determination des prix de revient de developpement dans un systeme interconnecte de production-distribution", Union Internationale des Producteurs et Distributeurs de'Energie Electrique, VI(10):1-35. Translated in Nelson, J. 1964, "The determination of costs of expansion of an interconnected system of production and distribution of electricity", Marginal Cost Pricing in Practice, Prentice Hall Inc, Englewood Cliffs.

Bonbright, J. (1961). "Principles of Public Utility Rates", Columbia University Press, New York.

Boyd, J., (1998), "The "Regulatory Compact" and Implicit Contracts: Should Stranded Costs be Recoverable?", The Energy Journal, 19(3): 69-83.

Brennan, T. and Boyd, J. (1997), "Stranded costs, takings, and the law and economics of implicit contracts", Journal of Regulatory Economics, 11(1997): 41-54.

Buhr, B. (2017), "Assessing the sources of stranded asset risk: a proposed framework", Journal of Sustainable Finance \& Investment, 7(1): 37-53.

Burness, H. and Patrick, R. (1992), "Optimal Depreciation, Payments to Capital, and Natural Monopoly Regulation”, Journal of Regulatory Economics, 4(1): 35-50.

Caldecott, B. (2015), “Avoiding stranded assets" in State of the World 2015 : Confronting Hidden Threats to Sustainability, Island Press/Center for Resource Economics. pp. 51-63, 2015.

Caldecott, B. (2017), "Introduction to special issue: stranded assets and the environment", Journal of Sustainable Finance \& Investment, 7(1):1-13.

Caldecott, B., Dericks, G. \& Mitchell, J. (2015) "Stranded assets and subcritical coal: the risk to companies and investors", Smith School of Enterprise and the Environment, University of Oxford.

Covington, H. (2017) "Investment consequences of the Paris climate agreement", Journal of Sustainable Finance \& Investment, 7(1): 54-63.

Crawford, G. (2014), "Written-down value? Assessing proposals for electricity network write-downs", Energy Networks Association, Canberra.

Crawford, G. (2015), "Network depreciation and energy market disruption: options to avoiding passing costs down the line", Economic Analysis \& Policy, 48(2015): 163-171.

Crew, A. and Kleindorfer, P. (1992), "Economic Depreciation and the Regulated Firms under Competition and Technological Change", Journal of Regulatory Economics, 4(1): 51-61. 
Decker, C. 2016, "Regulating networks in decline", Journal of Regulatory Economics, 49(2016): $344-$ 370 .

Douglas, S., Garrett, T and Rhine, R. (2009), "Disallowanecs and overcapitalisation in the US Electric Utility Industry", Federal Reserve Bank of St Louis Review, 91(1): 23-31.

D’Souza, J. and Jacob, J., (2001), "Electric Utility Stranded Costs: Valuation and Disclosure Issues", Journal of Accounting Research, 39(3): 495-512.

Graffy, E. and Kihm, S., (2014), "Does Disruptive Competition mean a death spiral for electric utilities?", Energy Law Journal, 35(1): 1-44.

Grant, H. (2016), “Assets or Liabilities?”, Energy Users Association of Australia, available at http://www.euaa.com.au/files/documents/Assets-or-Liabilities-The-Need-to-Implement-FairRegulatory-Valuations-for-Australia-s-Electricity-Networks-Final-Version-5-May-2016.pdf. Accessed December 2016.

Green, J. \& Newman, P. (2017) "Disruptive innovation, stranded assets and forecasting: the rise and rise of renewable energy”, Journal of Sustainable Finance \& Investment, 7(2): 169-187.

Hirst, E. and Hadley, S., (1998), "Designing True-up Mechanisms to Recover Transition Costs" The Electricity Journal, 11(8): 61-70.

Hoecker, J. (1987), "Used and useful: Autopsy of a Ratemaking Policy”, Energy Law Journal, 8(1): 303-335.

Hogan, W. (1994), "Stranded assets and the transition to competition", Harvard Electricity Policy Group Presentation, 12-13 May, 1994.

Hotelling, H., (1925), “A General Mathematical Theory of Depreciation”, Journal of the American Statistical Association, 20(151): 340-353.

Hotelling, H., (1938), “The general welfare in relation to problems of taxation and of railway and utility rates", Econometrica, 6(3): 242-269.

Joskow, P., (1996a), “Does Stranded Cost Recovery Distort Competition?”, The Electricity Journal, $9(3): 31-45$.

Joskow, P., (1996b), "How Will It All End? The Electric Utility Industry in 2005", The Electricity Journal, 9(1): 67-73.

Joskow, P. and Schmalensee, R. 1986, "Incentive regulation for electric utilities", Yale Journal on Regulation, 4(1): 1-49.

Kahn, A. (1970), The Economics of Regulation: Principles and Institutions - Volume I Economic Principles. John Wiley \& Sons, New York.

Kahn, A. (1971), The Economics of Regulation: Principles and Institutions - Volume II Institutional Issues. John Wiley \& Sons, New York.

Keay, M. (2016), "Electricity markets are broken: can they be fixed?”, The Oxford Institute for Energy Studies, Paper EL17, University of Oxford.

Kind, P. (2013), "Disruptive challenges: financial implications and strategic responses to a changing retail electric business", Edison Electric Institute, Washington DC.

Kruitwagen, L., Madani, K., Caldecott, B \& Workman, M. (2017), “Game theory and corporate governance: conditions for effective stewardship of companies exposed to climate change risks, Journal of Sustainable Finance \& Investment, 7(1):14-36.

Kydland, F. and Prescott, E. (1977), "Rules rather than discretion: the inconsistency of optimal plans", The Journal of Political Economy, 85(3): 473-492. 
Lintner, J. (1965), “The valuation of risk assets and the selection of risky investment in stock portfolios and capital budgets", Review of Economics and Statistics, 47(1): 13-37.

Lucas, A. (2016), "Stranded assets, externalities and carbon risk in the Australian coal industry: The case for contraction in a carbon-constrained world", Energy Research \& Social Science, 11(2016): 53 66.

Madian, A., (1997), "Meaningful Restructuring: Resolving the Stranded Cost Dilemma", The Electricity Journal, 10(1): 62-71.

Maloney, M. and Sauer, R., (1998), “A Principled Approach to Stranded Cost Issue”, The Electricity Journal, 11(3): 58-64.

Martin, J. (2001), "Stranded Costs: An Overview", Universitat Pompeu Fabra and CEMFI, Working Paper No. 0108, June 2001, pp 1-46.

McArthur, J. (1998), “Avoiding the mistakes of FERCs and California's full stranded-cost recovery”, The Electricity Journal, 11(2): 57-67.

Mercure, J., Pollitt, H., Viñuales, J., Edwards, N., Holden, P., Chewpreecha, U., Salas, P., Sognnaes, I., Lam, A. and Knobloch, F. (2018), "Macroeconomic impact of stranded fossil fuel Assets", Nature Climate Change, 8(July): 588-593.

Michaels, R., (1995). "Stranded Investment Surcharges: Inequitable and Inefficient." Public Utilities Fortnightly, May 15: 21-25.

Michaels, R., (1998), “Securitized Transition Costs: Rethinking Who Wins and Who Loses”, The Electricity Journal, 11(5): 58-65.

Myers, S. (1972) "The Application of Finance Theory to Public Utility Rate Cases", Bell Journal of Economics, 3(1): 58-97.

Navarro, P. (1996), “Ten Key Questions for the Restructuring Regulator”, The Electricity Journal 9(7): 65-70.

Nelson, T. and Orton, F. (2013), “A new approach to congestion pricing in electricity markets: Improving user pays pricing incentives”, Energy Economics, 40(2013): 1-7.

Officer, R. (1994), "The cost of capital of a company under an imputation tax system", Journal of Accounting and Finance, 34(1): 1-17.

Pagach, D. and Peace, R., (2000), “Utility Deregulation and Stranded Investments” Critical Perspectives on Accounting, 11(5): 627-644.

Pfeiffer, A., Vogt-Schilb, A., Tulloch, D. \& Hepburn, C. (2018), "Dead on arrival? Implicit stranded assets in leading IAM scenarios”, INET Oxford Working Paper No. 2018-08, University of Oxford.

Peltzman, S. (1976), "Towards a more general theory of regulation", Journal of Law and Economics, 19(2): 211-240.

Pierce, R. (1984), “The Regulatory Treatment of Mistakes in Retrospect: Cancelled Plants and Excess Capacity”, University of Pennsylvania Law Review”, 132(March): 497-560.

Posner, R. (1974), “Theories of Economic Regulation”, The Bell Journal of Economics and Management Science, 5(2): 335-358.

Rose, K. (1996), “An economic and legal perspective on electric utility transition costs”, the National Regulatory Research Institute, Columbus.

Rozenberg, J., Vogt-Schilb, A. and Hallegatte, S. (2019), "Instrument choice and stranded assets in the transition to clean capital", Journal of Environmental Economics and Management, article in-press. 
Ritschel, A. and Smestad, G., (2003), “Energy subsidies in California's electricity market deregulation”, Energy Policy, 31(2003): 1379-1391.

Schmalensee, R., (1989), “An Expository Note on Depreciation and Profitability Under Rate-of-Return Regulation”, Journal of Regulatory Economics, 1(3): 293-298.

Sharpe, W. (1964), “Capital Asset Prices: a theory of market equilibrium under conditions of risk", Journal of Finance, 19(3): 425-442.

Silver, N. (2017) Blindness to risk: why institutional investors ignore the risk of stranded assets, Journal of Sustainable Finance \& Investment, 7(1): 99-113.

Simshauser, P. (2014a), "From first place to last: the National Electricity Market's policy-induced energy market death spiral", Australian Economic Review, 47(4): 540-562.

Simshauser, P. (2014b), "The cost of capital for power generation in atypical capital market conditions", Economic Analysis \& Policy, 44(2014): 184-201.

Simshauser, P. (2016), "Distribution network prices and solar PV: resolving rate instability and wealth transfers through demand tariffs", Energy Economics, 54(2016): 108-122.

Simshauser, P. (2017), "Monopoly regulation, discontinuity and stranded assets", Energy Economics, 66(2017): 384-398.

Simshauser, P. (2018a), "Missing money, missing policy and Resource Adequacy in Australia's National Electricity Market”, EPRG Working Paper No.1821, University of Cambridge.

Simshauser, P. (2018b), "Price discrimination and the modes of failure in deregulated electricity markets", Energy Economics, 75(2018): 54-70.

Stigler, G. (1971), "The theory of economic regulation", Bell Journal of Economics and Management Science, 2(1): 3-21.

Tye, W. and Graves, F., (1996), "Stranded Cost Recovery and Competition on Equal Terms", The Electricity Journal, 9(10): 61-70.

Wen, S-Y. and Tschirhart, J., (1997), "Non-Utility Power, Alternative Regulatory Regimes and Stranded Investment”, Journal of Regulatory Economics, 12(3): 291-310.

Woo, C., Lloyd, D., Karimov, R. and Tishler, A., (2003), "Stranded cost recovery in electricity market reforms in the US", Energy, 28(1): 1-14. 


\section{RESEARCH HIGHLIGHTS}

A policy for stranding regulated assets under uncertainty is presented

Excess capacity is Parked, and credit-wrapped bonds are issued

Bond issuance ensures the utility remains financially stable

Tariffs are then reduced, and assets are Unparked over time 